\title{
BESOGNES DER HOOGE REGEERING TE BATAVIA GEHOUDEN OVER DE COMMISSIE VAN PARAVACINI NAAR TIMOR 1756.
}

DOOR

\section{P. A. LEUPE.}

"Koepang omstreeks 1750 " is de titel van een opstel van Mr. J. A. van der Chịs in het Tịjdschrift voor Indische TaalLand- en Volkenkunde, D. XVIII. Zeer juist schetst de schrijver naar aanleiding van het Rapport van den in 1756 naar Timor gezonden Commissaris J. A. Paravacini den toestand van de dienaren der Compagnie en die der burgerij aldaar, terwiji hij ons tevens een staaltje geeft van de wịjze waarop de Compagnie met de aan haar ouderworpen volken omsprong. Ter aanvulling van het door den Heer van der Chijs ons medegedeelde kan het wellicht niet overtollig wezen bekend te worden, hoe de Hooge Regeering te Batavia de zending van Paravacini opvatte en welke besluiten zij daaromtrent nam; wij vinden dit opgeteekend in hare vergaderingen van Maart, April en Mei 1757.

Den 29 Maart verscheen de Gouverneur-Generaal Mossel in de vergadering, en nadat er eenige voorafgaande zaken waren afgehandeld, stelde hij voor om een aanvang te inaken met het Besoigne over het commissoriaal rapport van den gewezen Commissaris der Regeering Paravacini, concernerende zijne verrichtingen te Timor, dat op den 25 te voren geen voortgang had gehad.

"De Leden" sig daarmede confirmerende, "gaf sijn Edel"heid de vergadering bij wege van introductie te kemnen, dat "(hij) uyt hoofde van zijne zwakheid, thans niet in staat was een "lang discours te doen over dat schriftuur en de verrigtingen "daarbịj in 't breede gedetailleerd, dog dat hị na sijue ge"dagten het zakelijke daar uyt ten papiere hadde gebragt, en 4e Volgr. I. 
"vermeende het zelve van die aangelegenheid en consideratie te "wezen om op die poincten het nodige te resolveren". $\mathrm{Na}$ het lezen van dit geschrift, werd het op zijn verlangen ingeschreven. Wij teekenen daaruit zoo bekmopt mogelijk het volgende op.

Hij oordeelde de handelingen van den Commissaris in het algemeen nuttig en voordeelig, zoo omtrent de Vorsten als de behaalde voordeelen.

Er was verder een goed Opperhoofd noodig "om dat wel gelegt werk te voltooien", waaraan men tegen het najaar wel mocht denken.

De goudmijn, waarbij de Post aangelegd was en die van Belo, diende te worden onderzocht en bewerkt, volgens het voorstel of naarmate men arbeiders kon bekomen, tot welk einde men een partij Balische slaven naar Tinor moest zenden. De glinsterende erts kon als een proef naar Nederland worden verzonden.

De indigo-cultuur kon men beproeven, doch moest men dit niet "te sterk aantasten ", omdat het een groote lastpost was.

De peperplantjes kwamen wel op, en zoo die daar wilden aarden, mocht men er iets goeds van verwachten, doch hieromtrent moest geèn dwang plaats hebben.

Met den Koperberg had het mede geen groote haast "om niet te veel gelijk overhoop te halen"; een oplettend opperhoofd zou daaromtrent zijn tijd wel weten te kiezen.

De inkoop van was à 28 rijksd. de 125 pond, was zeer voordeelig tegenover 48 rijksd., die nu te Batavia daarvoor werden besteed.

De inzaam van het saudelhout kon nu niet schaden dewijl de prijs van 7 op 3 rijkssd. was teruggebracht.

Van de monsters lijwaten op Timor vervaardigd, diende een nadere proef te worden genomen; in het bijzonder van die soorten die op Batavia werden gezocht, enz.

Sumba 1-verdiende opmerking; intusschen moesten overal op de omgelegen eilanden merkpalen worden geplaatst, en een korporaal of tolk die schrijven kon.

De Zwarten, die onder den. Tenenty (Teniente) of Luitenant Generaal van Toelan Ikan stonden, hadden wel verdiend te worden ten ondergebracht, wanneer zij zoo stout waren om de Compagnie aantevallen, zonder naar den Portugeeschen Gouverneur

\footnotetext{
1 Soemba $=$ Sandelhout $P$ Eiland.
} 
te hebben willen luisteren. Doch nu diende men daartoe weder eene gelegenheid aftewachten en dan ongevraagd alles aan te wenden tot hun geheelen ondergang en verdelging der Landen onder de Timoreesche Koningen, zonder de blanke Portugeezen van Liffao, noch priesters, noch kerken te benadeelen

Over het bedrog van den Klein Winkelier moest men verantwoording vorderen.

Snaphanen, kruid en lood en wat de Compagnie in hare pakhuizen in voorraad had, moest men tot geschenken zenden en den inkoop zooveel mogelijk vermijden.

In de zaak van Lando vond hij alle omstandigheden en den aanleg met volkomen genoegen der bondgenooten, waarvan zulke zaken dependeerden en ook uitgevoerd worden, gevolgelijk ook te billijker, dat, daar de Landonezen de wapenen tegen de Compagnie opgevat hadden en de Vaandrig - het Hoofd der Militie - daarbij was gesneuveld, men hunne krịgsgevangenen tot slaven had verklaard en onder hen verdeeld, wat er ook op het woord Pardon mocht aangemerkt worden, ofschoon het immers niet te scheiden was van het bijgevoegde woord op discretie. Dit hadden zij zich onwaardig gemaakt, door na de overgave weder opstand te verwekken, die zonder tusschenkomst van de Compagnie niet te dempen was geweest.

Bovendien, er hadden zich in het geheel slechts omtrent 700 overgegeven, waarvan er 2 à 300 weder waren ontslagen en bleven er ten minste 400 krijgsgevangenen, onder den geheelen hoop van 1400 inlanders, over en die naar Batavia waren gezonden. De overigen waren gekochte slaven, en diegene die gedurende het beleg dagelijks in de gedane uitvallen als anderszins gevangen waren geraakt, en waarop, hoe men het ook nam, het parool (pardon) niet vau toepassing was. Behalve dit was in dezen gehandeld naar de oude usantiën en gebruiken tot dezen tijd toe, met dit onderscheid, dat vroeger de Compagnie omtrent $\frac{1}{10}$ en de dienaren een goeden hoop kregen; nu had de Compagnie alles en de Commissaris niets. Want het voorgeven dat de Commissaris 300 krijgsgevangenen zou hebben naar zich genomen en overgezonden, nam hịj, GouverneurGeneraal, op een "simpel" zeggen niet aan; dit diende bewezen en hij daarover gehoord te worden.

De Gouverneur-Geueraal verklaarde derhalve ieder, die van Timor overgekomen was voor slaaf, latende ze aan een ieder die hij naar gewoonte wettig gekocht of verkregen had, en 
"denke alle, die daaronder als krijgsgevangen overgesonden sijn, "ten behoeve van de Compagnie te moeten blijven, 't sij dat "deselve verkocht of in haren dienst gebruikt worden."

Den verkoop te Timor verklaarde hij mede voor wettig en wel (g̊edaan). Het Hoofd Geolima, mede overgekoinen en van vele misdaden nevens zijne zoons beschuldigd, was "oud en caducq" en beloofde geen lang leven; zijn oudste zoon was overleden, de tweede een assurante knaap. Geolima was niet zoo gevaarlijk te achten, maar de zoon "onder een hoop der synen periculeus."

Alle die menschen waren tot nog toe onderhouden en kostten de Compagnie reeds 40 lasten rijst, die hij verzoekt dat afge. schreven mocht worden.

, De tractaten met de Vorsten gesloten $\mathrm{v}$.nd hị heilzaam en boven verwachting; "des applaudere en ratificere ik deselve "in haren geheelen zakelijken inhoud; integendeel desavouere "ik zeer, zekere periode bij art. ऽ 1, die bij acte van ratificatie ${ }$ kan gesecludeert worden en geroijeerd door den eersten clercq, "ow alsdan de verbeterde copye na Timor te senden, dewijl "'t onbetamelıjk is, sodanig van gekroonde Hoofden te spreken "en waarover Paravicini een ernstige reproche verdiend."

Het volk, dat de bondgenooten beloofden in de wapenen te zullen houden, "moest men na hare comoditeit laten, als 't "niet" op ankomt."

De aanval op de zwarte Portugezen moest men uitstellen tot men er de gelegenheid toe geeft en alsdan de bondgenooten met alle vermogen te hulp komen.

Die van het Oosterdeel van Ende of Larantneka moest men vriendelijk behandelen en zoo zien te onderwerpen, of bij een een goede gelegenheid die er mocht voorkomen en niet bepaald kon worden, dan wel door een huwelijk aan Solor zien te trekken, maar vooral openbaar geweld vermijden.

Het tractaat met Liffao was wel aan te gaan, mits met uitsluiting van anderen. De nagelaten memorie aan het Opperhoofd van Timor vond hịj wei gesteld, en diende noodzakelijk te worden nagekomen, maar het opzenden van Koepangs Koning kon nagelaten worden, zoo lang men het er mede kou stellen.

Lissolot moest men naar bevindiing van zijn gedrag behandelen. De negotie moest volgens voorschrift gedreven worden.

1 Zie het advies van derwnhldacede 
De burgers, die zich te veel met de Vorsten inlieten, moest men met de benoodigde bewijzen opzenden, en nooit toelaten dat iemand der Europeesche of der hunne, behalve het Opperhoofd, aldaar eenig gezag uitoefende, hetzij onder den naam van voogdijschap of wat het ook wezen mocht.

Bij de papieren vond de G.-G. hier en-daar "passagiën, "die wel een ernstige behandeling jegens den opstelder souden "meriteren, maar considereren, dat in dat merkelijk embras, "'t welk een geheel mensch konde occuperen onder soveel ge"schrifts, de gedachten wel eens buyten 't spoor hebben willen "lopen, echter is die buitensporigheid niet te passeren sonder "een ernstige reproche, en als ik wijders aanmerk de gedane "diensten en de onvermijdelijke vlijt en arbeid, in syne eom"missie ten koste gelegd, kan ik buyten dit wel een generaal "genoegen in syne verrigtingen nemen."

Het oordeel over de verrichtingen van Paravacini te Timor door den Directeur-Generaal van der Parra, was op ver na niet zoo gunstig voor dezen, als dat van den GouverneurGeneraal. Ook van der Parra had zijn advies in schrift gebracht en daarbij eenige bijlagen gevoegd, en verzocht dat die stukken of bij resolutie van dien dag werden ingeschreven of in copie naar het vaderland mochten worden gezonden "ter believe ende "speculatie der Heeren Meesters, nadat alvorens twee bijlagen "behoorlijk zouden wezen geauthentiseert. $\mathrm{H}_{\mathrm{ij}}$ drong bovendien "aan om te obtineren een behoorlijke reparatie en satisfactie "wegens de belediging, Sijn Edele in sijn caracter en 't ampt „van Directeur-Generaal, door dese en geene expressiën in het "rapport gevonden wordende."

$\mathrm{Na}$ het lezen van deze geschriften besloot men die te insereeren. Zijn eerste opmerking is gewijd aan de aangegane contracten, "die bij dat rapport - zegt hij - den titel van overheerlijke en voordeelige " gegeven worden; doch die in hunne gevolgen mogelijk daarvan geen schaduw zullen kunnen geven. Hij wenscht zich voornamelijk nopens het 5 de artikel van de acte van verbond en voorwaarden, met de gezamenlijke Koningen en Regenten van Timor aangegaan, te refereeren aan het aangebodene protest, mitsgaders, ten aanzien van de periode van meergemeld rapport: "Immers werden daardoor alle intrigues vau Portugal "Inet Vrankrijk of wien 't ook soude mogen lusten, sig van desen „sleutel van den Oosterschen archipel meester te maken, gant. "schelijk verijdelt; hebbende met dit miju nieuw verbond en de 
"nieuwe bondverwanten, de Portugesen van meest alle domeynen, "ja zelfs van hun Hoofd Comptoir Liphao ontroofd, want die "Koning die dit grondgebied toekomt heeft sig selfs met al het "Land dat hij bezit, waaronder Liphao behoort, an d'Edele. "Comp. onderworpen en overgegeven", aanhalen, dat, ofschoon na deze stelling de Portugeezen van alle hunne domeinen en zelfs van hun hoofdkantoor Liphao ontroofd waren, het echter zeker was, dat zij "regt ter contrarie met 't meesterschap in "handen daar gezeten bleven", en gevolgelijk dat die progressen maar op het papier waren gemaakt. En wat staat er in het algemeen te maken was op de contracten of het woord van de Koninkjes, vond men aangeteekend bij de Memorie van $\mathrm{Pa}-$ ravacini aan het Opperhoofd Beynon achtergelaten; daar werd op bl. 11 gezegd: "die in 10 dagen honderdeley gevoelens heeft, "en die altemaal met capricieuse en hartnekkige sentimenten "staaft."

Behalve dit zou de Grootvorst van Belo en souverein Koning van Wywịko, Bahale enz. naar zijn naam Hiacinto Correa, een Roomschgezinde moeten zijn, die zich immers onder geen ander geloofsgenoot met ernst of goedwilligheid onderwierp. Die onderwerping kwam derhalve den Direct.-Gen. zeer bedenkelijk voor, als een zaak waarop niet veel te rekenen viel, en dit te meer als men opmerkte, dat bij de memorie waar van de Vorsten werd gesproken die door het zwaard waren overwonnen, de volgende uitdrukking gevonden werd:

"Want de oude liefde voor de Portugeezen hare grootsche "en trotse wijse van ageeren, die so wel met die der Indianen "accordeert, denselver Roomschen godsdienst die sij nog belijden, "de moeyten en listige aanslagen der geestelijke om se weder "onder 't oude juk te brengen, de groote distantie van hunne „rijken van ons, en de nabịheid der zwarte Portugeezen, de na"tuurlijke haat en wrok (alle geringe verstanden gemeen) die "sij hebben tegen haar die haar verovert hebben, de geringe "achtinge der vijf Koningen, sijn allemaal hinderpaalen, die "men moet zien door een liefdadige en menschelijke wijse van "ageeren uyt den weg te ruymen en uyt hare gedagten te ver"bannen."

Hierop volgde "deze aanmerkelijke annotatie:"

"Dog wat aangaat de derde of laaste classe, namentlijk die "geen, die sig door mijn toedoen goedwillig onder 's Comp. "protectie hebben begeven, als de Koningen van Wywiko, 
"Bahale, Souay en Liphao moeten nog vrij wat distincter, om"sigtiger, beleefder, heuscher en edelmoediger als de twee eerste "soorten werden getracteerd.

"Dese waurheyt'schijnt uyt de zaak selfs als onwedersprekelijk "te vloeijen, eensdeels om deselve redenen, die ik in de tweede "classe hebbe g'allegueert, anderdeels, om dat sij maar een "stap te doen hebben, om bij hunne oude bondgenoten te "komen, sonder dat wij door de verhijt daarin konnen voorzien.

"UEd. is ook bekend, dat se in eer, deugt, goede en gesonde wsentimenten, schranderheyd, trouw en civiliteyt, so wel de "tweede overtreft ais de tweede de eerste, dat de alderslegtste "en laagste is.

"Dese moet men met eene ongemeene vriendelijkheyt en "distinctie handelen, en als men haar ontbied, so moet sulx "met beleefde en verpligtende termen geschieden als of men "verlangde haar te sien, en den trouwe bondgenoot van d'Edele "Comp. gaarne wilde spreeken, om occagie te hebben, haar van "de goedmeenentheyd der E Comp. tot haar te onderhouden, en "beschenken haar als dan met eenige kleinigheden al was het "ten koste van d'E. Comp. mits men hare contra presenten ten "favcure van deselve inneemen."

De Direct.-Gen. kon zich ook niet vereenigen met den inhoud van het $23 \mathrm{e}$ artikel van de genoemde acte, waarbij onder anderen de Koningen enz. zich verbonden gratis te zullen leveren en bezorgen, allerhande soorten van levensmiddelen, als buffels, schapen, varkens enz., zoomede houtwerken, bamboes, atap, sparren, kalk, steenen, alsmede andere benoodigdheden, doordien hij vermeende, dat, om te voorkomen het misbruik dat daarvan zou kunnen worden gemaakt, voor het een zoo wel als voor het ander een vasten prịs diende bepaald en gegeven te worden. $\mathrm{H}_{\mathrm{ij}}$ was mede van gedachte, dat $\mathrm{P}$. op eene voldoende wijze zou moeten bewijzen waar de honderd personen gebleven waren, die bij het veroveren van het rijk van Anthony Rotoetoe ge. vangen waren gemaakt, daar dit nergens uit bleek.

Wat de Koningen en Vorsten betrof, was hem o. a. het volgende voorgekomen:

"Want deze arme Koningjes waren van te voren gewend de " onversadelijke gierigaarts en tiraunen te contribueren voor ' $t$ "beslissen van humne geschilien, en die 't meeste goud of "slaven gaf, kreeg, schoon tegen alle regt en reden, 't meeste "gelijk; en dan bleef de zaak nog maar in deselfde crisis, tot 
"dat er die ongeneeselijke wonden, welkers genesing mij te "beurt moeste vallen, uyt outstonden:"

Hij was van gevoelen, dat P., die daarvan kennis scheen te dragen, ook opgeven moest welke Opperhoofden zich daaraau schuldig hadden gemaakt om zoo mogelijk naar eisch te worden gestraft.

De zinsnede : - "Niemand wilde voor een ander onderdoen; "als het Opperhoofd iets gelaste, antwoorden de Bedienden, "so Officier als Oppermeester en meer anderen, met het wer"pen van huune hoeden voor syne voeten. Ik verdom 't om "dit of dat te doen." - en de daarop volgende:- "De soldaten "sworven met hunnen Officier in de Tapkroegen en gehoor"zaamden niemand meer, in so verre, dat als 't Opperhoofd eens "een soldaat die bij hem de wagt hadde, vriendelijk versogt sijn "snaphaen te willen schoonmaken, dese hem toesnauwde: dat "wil ik niet doen, ik hebbe werk genoeg, gij kunt 't selfs "doen" - gaven zoowel als een voorgaande van een zekeren daarbij vermeld wordenden spotboef, die het Opperhoofd, onder het toeroepen in den nacht van een verraad van den Koning van Amabay opgewekt had om hem dus te bespotten, den Direct.-Gen. aanleiding, om te sustineren, dat de namen van alle die arrogante en strafwaardige sujetten niet alleen dienden opgegeven en opontboden, maar ook in handen van den Advocaat Fiscaal gesteld, om daardoor te beletten dat "de subordinatie "niet ten eenmaal den rug ingereden wert."

Verder wees hij op "de fraaie en mogelijk zoo lang als de Nederlandsche Maatschappij gestaan had,“ niet bekende passages in papieren van een mindere aan zijn meerdere, van den volgenden inhoud:

"Edog voor dat ik daartoe overga, ben ik om mijn caracter, "eer en fatsoenhalven, dat mij so lief, ja liever als mijn leeven "is, genoodsaakt, hoe ongaarne ik dese stap ook doe, mijn "regtvaardig ressentiment over twee poincten in de missive aan "de Ministers van Coupang ter neder gestelt te betoonen; 't "eerste bestaat daarin dat UwHoogEdelens de Ministers van dat "comptoir, die mijn subalterne uyt de Natuur, en 'volgens Uw "HoogEdelens ordres moesten worden en met myn komst aldaar "wesen, aanschryft, de redenen van mijne komst, als of de mindere " ook moest weten tot wat eynde de meerdere of die haar volstrekt "uyt uw HoogEdelheder namen gebieden sou daar quam ver"rigten, seggende uw HoogEdelh. in der selver aan dese Ministers 
"g'addresseerde missive, dat ik eenlyk gesonden was om met dies "te meer luyster de contracten te vernieuwen. En dat was van "sodanig quaad effect, dat sij, die met mijne komste wegens "hunne quade concientie van benautheyt beefden, mij nu uyt"lagten, soodra sij den aan haar g'adresseerden brief gelesen hadden. "Het tweede poinct mijner beswaarnisse is, over 't schrijven in "die selfde missive en aan de selfde Ministers, dat't Opperhoofd "Beynon my by myne komste de regeering moest overgeven, gelijk "sulcx van selvs spreekt, dog dat de goederen en koopmanschappen "onder berusting van 't Opperhoofd Beynon souden moeten "blijven.

"Wat wil dat (met eerbiedig verlof HoogEd. Heeren en Wel "Edele Heeren gesproken) anders seggen of te keunen geven, "als dat die goederen beter vertrouwt sijn aan den subaltern, "als hem die her gebied en gesonden is om zijne zaken te "ondersoeken. Strekt dat niet grotelijks tot declin en veragting "van mijn eer, fatsoen en caracter, ja selfs van uw HoogEdelh. "die mij hebben gesonden, om als humnen expressen Commissaris, "die so luysterrijke Regeering te representeeren. Want is hij meer "te vertrouwen dan ik en uyt hoofde van dien de goederen in "sijn magt en bewaring moeten blyven, konde immers die com"missie om met den Liphaosen Gouverneur te contracteren als "een zake van 't uyterste gewigt, in stede van aan mij, wel "aan hem opgedragen sijn geworden, te meer, om dat daartoe "geld of goed moet sijn, dog van welke beyde articulen ik in "gevolge van dese aanschrijving "so wel als een pad van veeren" "voorzien was.

"Het aanschrijven vau deze periode, so stom en stupide 't "Opperhoofd is, wist hij echter bijzonder wel, en so goed als nde Resident van Palembang, die 't mede angeschreven was, "mij de Regeering over alles, behalve over de comptoirs "zaken overtegeveu. (NB. en auders siju der immers geene als "comptoirs zaken op Palembang) bij zeker occagie, dat ik goederen "uyt de pakhuyzen benoodigt was, tot sijn voordeel te alle"gueeren; maar ik stoorde mij om de waarheyt te zeggen seer "weynig aan zijne allegatien; toonende dat ik volstrekt meester "was, en dat tot mijn depart soude blịven.

"Dese misselijke perioden sijn 't voorwerp van mijn gedurig "murmureeren in mijne lastige commissie geweest, niet kunnende "bevroeden waaruyt die haar source hebben genomen; te meer "ik sulke groote en ik mag seggen preuven sonder voorbeeld, 
"in mijn voorgaande commissie na Palembang hebbe gegeven, "daar ik in stede van mij, so als dikwyls de gewoonte is, te "verrijken, 3000 Rds. ben te kort gekomen; want ben ik niet "te vertrouwen, waarom mij dan sulke gewigtige commissie "opgedragen?

"Ik versoeke ootmoedigst HoogEdele Heere en WelEdele "Heeren, mij mijn vrijpostig ressentiment over dese kleynagting "en wantrouwen te pardonneren; want de pil is te bitter om "neergeslikt te worden, sunder mijn gevoelen over haar bit"terheyt, egter met alle mogelijke eerbied eenigemate te laten "blijken; te meer omdat ik hier niet spreek als een Oppercoop"man, maar als een persoon, die Uw HoogEdelhedens hebben "verwaardigt als hunnen Commissaris, om hare illustre Personen "te representeren, te nomineren.

"En sodanige persoou moet sijn fatsoen en caracter so lief"hebben en weten te maintineren als die geen die hem aan"gestelt hebben. Hij moet ten minsten in sijne functie excelleren "en irreprochabel sijn, wil hij 't portrait en afbeeldsel sijn , "van diegeene die hem gesonden hebben, bij gevolg vol ver"trouwen."

"Had mij mijue ervarentheyd geen middel aan de hand ge"geven om geld te furneren, en 't Opperhoofd had sig aan 't "hem aangeschrevene namentlijk, dat de goederen in sijn bewa"ring moesten blijven, gehouden, waarmede soude ik, nog eens "met eerbied gevraagt, het becontracteerde van Liphao', daar "sig Uw Hoog Edelh. als een poinct van de uyterste noodsa"kelijkheyd, soo 't schijnt so sterk aangelegen laten sijn, be"taald hebben? Geld was er niet en over de goederen kou ik "niet disponeren; sijnde mij nog bij mijne instructie geordonneert " $e e n$ goeden prijs voor ' $t$ bedongene te geven, maar ' $t$ aanwijsen "Waar ik dat van daan moest halen, is in de pen gesmoord."

Daarover zou de Directeur-Generaal de moeite sparen "om "in dese aan te toonen de insupportable arrogantie, imperti"nentie, ja selver laesie, 't geheele lichaam deser Regeering "aangedaan wordende, en maar kortelijk van advis sijn:" dat hij P. tot een exempel van anderen en om hem te leeren zich te houden binnen de palen van zijne subordinatie, voor den tijd van een jaar en zes weken, diende te worden gesuspendeerd van ambt, kwaliteit en gagie of ten minsten te worden gecondemneert in eene boete van 1000 ducatons ten behoeve van de armen te Batavia. 
Daar P. "op eene walgelijke wyse kwam te swetsen op sijne genereusheyt" waarvan maar al te wel het tegendeel stond te worden aangetoond, wenschte de Directeur-Generaal dat P. aanwijzen moest, "hoe hij aan een excessief groot getal van 300 "vrye mensehen geraakt was, die hij als slaven opgesonden had "aan den Landdrost den Heer Jan Jacob Corp en den Capitain "Ingenieur Berg (dog door welke dese commissie was van de "hand gewesen)." Zoo ook waar gebleven was 't geen voor een partij op Timor bij zijn aanwezen geloste Landoneezen was opgebracht geworden. Wat P. aanhaalde nopens de aamınerkelijke winsten door hem aan de Compaguie toegebracht, hiervoor verwees de Directeur-Generaal naar de aanmerkingen in margine van zijn ingedienden Staat rekening gesteld en die hij hierbij voegde.

Verder deze zinsnede: "hebbende niet alleen de zware lasten "deser commissie, om 's Comp. credit en Uw Hoog Edelhedens "luyster onder de Vorsten, Bondgenoten, maar ook insonderheyd " onder de nieuwe door mị tot d'Ed. Comp. overgehaalde "Bondgenoten, die haar door den uyterlijken schijn laten ver"voeren, en na rato van den uyterlijken pragt den Persoon "en die hem gesouden hebben, taxeeren, ongemeene kosten van "kleederen, so voor mijn als mijn equipage enz. moeten dragen, "en altijd een open tafel houden; maar ook meest alle de ge"schenken aan dese Vorsten, de pragtige maaltijd, de kosten "der oorlogs-expeditie na Rotty, de besending eener Commissie " over zee na Reymea, de groote expeditie na Beloe, item die "van Wywiko, Bahale, eene om s'Edele Comp. Bondgenoten "tegen de Naymotiers te beschermen, als ook die om de goud"mijn op te soeken en die uyt groote Heijeren (Heeren?) be"stonden, hebbe ik altemaal uyt mijn beurse goedgemaakt, "sonder d'Ed. Comp. iets daarvoor in rekening te brengen."

Hierover was de Directeur-Generaal van advies: dat zoowel van het een als van het ander eene behoorlijke rekening diende geformeerd en overgegeven te worden, "opdat het hoogvliegent ver"moeden van desen gewesen Commissaris niot beswangert rake, "met de verbeelding dat hij de Nederlandsche Maatschappij tot "sijnen debiteur daar voor houden en pretensiën forıneren kan "na sijn welgevallen, wanneer het hem gelegen mogte komen, "'t sij hier of in 't Patria."

Daar P. had gelast, de voor de Koninkjes derwaarts gezondene geschenken te verkoopen, en hen volgens zijn zeggen met 
het zijne te beschenken, kwam "dit gedoente (den Directeur"(ieneraal) vrij reprochahel voor", zoodat dit voor het vervoig diende verboden te worden. Hij moest (behalve het geen hij verder nog moest aanmerken) de Regeering tevens opmerken, dat die verkochte geschenken "een capitaal avans" hadden gegeven en bijgevolg van betere deugd en prijs als hij P. had kummen goedvinden "bij sijn rapport quaadaardig te beschrijijen."

Het is beschamend volgens de gedachten van den DirecteurGeneraal dat men, op het rapport van een man "die sig dub"beld waardig acht Commissaris van dese Regering te sijn" geen staat kon maken, maar moest ontwaren, dat men zich jammerlijk bedrogen zou kumnen vinden wanneer men zich zonder nadere papieren te doorloopen, daarop kwam te verlaten.

Want wat zou men gelooven vau hetgeen P. had geschreven, nopens de Mardijkers, die bij dat rapport worden genoemd "wel "geintentioneert en de E.Comp. bijsonder getrouw;" hetgeen regelregt streed met hetgeen hij van hen zegt in de nagelaten Memorie voor het Opperhoofd Beynon in deze bewoordingen: "Dat men met 't grootste regt des werelds kan dugten, dat "de twee broeders, IInofden der Mardykers, die seer bemind "sijn en een groote invloed op een ansienlyke magt hebben, "en geen katten sijn om bij een oproer sonder handschoenen "aan te tasten, de Comp. die se protegeert zullen handeleu, wals de blanke Portugesen door humen T'enenty-Generaal dikwijls "behandelt syn.

"Ik raade UE. om met dese menschen met de uytterste om"sigtigheyt te werk te gaan, tot ik op Batavia kome, en Haar "Hoog Edelen UEd. met een aarsienlyke magt in staat stellen "dese suaken te beteugelen."

Er volgen nu eenige opmerkingen omtrent het cultiveren van indigo en peper op Timor en Rotti en het touwwerk van Sumba (sandelhout). Hoewel het den Direct.-Gener. voorkwam, dat de groote opgave van dat eilaud, evenals zoo veel andere opgaven van den Commissaris, wel eens overdreven zouden kunnen worden bevonden kwam het hem echter voor, "dat men een expresse besending derwaarts moest doen tot een nader onderzoek van zaken."

De door P. voorgestelde ontvolking van dat eiland, dat volgens het gevoelen van den Direct.-Gener. niet dan met geweld zou kunnen geschieden, kon hij niet goedkeuren, doch 
wel om, zoo de menschen daartoe genegen waren, passagie naar Batavia te bezorgen.

"Het ongemerkt passeren van de periode: - "D'Officier "Zingelman, die ik hebbe mede gebragt, wil in 't stoken van "arak, als of dat sijn fatsoen te na was, den gegageerden Oehle "dienaangaande niets cederen, hebbende ook dikwils geprobeerd "de soldaten het hunne te onthouden; eene maxime die hy "sekerlyk op Batavia van die rijke t'huysvaarders geleert zal "hebben" - zou aanleiding kunnen geven, bij de Heeren Mcesters "ais of men strafwaardige gedoentens willens en wetens "gedoogde." Hij was daarom van gevoelen, dat P. moest opgeven wat hem daarvan bekend was en wel voornamelijk de namen van hen die zich daaraan hadden vergrepen.

De Direct.-Gener. verdedigt zich uitvoerig tegen $r$. als of er te veel toegegeven werd aan de gedane eischen van Timor, om behoeften, zooals planken, balken, verwstoffen, teer, kruid enz., als door den Direct.-Gener. geschiedende, "schoon het "hem (Direct.-Gener.) bịna niet de moeite waard soude sijn "geweest, de quaardaardige en valsche positiën van desen vol "van verwaandheid en inbeelding sig selfs in veeie opsigten ver"liesenden en al wat prodato gesuspecteerden Paravacini te "wederleggen."

Het artikel van het goud werd bij de Memorie niet alleen zeer gunstig beschreven, maar ook in het vooruitzicht (schoon in het onzekere) daarvoor tomnengouds voor reëele winsten gesteld; het gaf den Direct.-Gener. aanleiding, hoewel door verschillende zinsneden mogelijk zou kunien worden aangetoond, dat men hier weder gelijk wel voorheen "een goudinijn opdiste, daar "men goud zoekende kwalijk ziiver vinden za!," dewijl in het door $P$. aangebrachte zand uic de goudrivieren, ook eenige aarde bij den zeer kundigen Essayeur Villeers geen goud, maar siechts een klein greintje zilver in ieder was gevonden, en zoo weinig dat het op verre na de onkosten niet zou kumen goedmaken, echter van die hoedanigheid, dat men, om van de zijde der Regeering alles aantewenden wat mogelijk was "om achter de ware gesteltheyt van dese breede opgave te geraken" P. met den titel van Directeur over de goudınijnen van 'Timor (rooals weleer omtrent Sillida 1 was geschied) weder naar derwauts diende te worden gezonden, ten eiude

1 Westkust van Sumatra. 
het begommen werk "te perfectioneeren, waartoe met geen de "minste hope, dat er bij de minste hapering geen reproche of "honderden van tegenwerpingen van hem P. zouden voor den "dag worden gebragt, eenig ander subject kan worden ge"ëmployeerd."

Ongerekend nog, - voegt de Direct.-Gener. er bij, dat het naar zijn gedachten op verre na niet genoeg was, vertooningen van importante zaken op het papier te maken of de grootste opgaven te doen, zonder de realiteit daarop te laten volgen, daar men anders de Heeren Meesters, die men jammer genoeg "door een geheele vleet van projecten meer dan "eens in den slaap heeft trachten te wiegen, om mar een naam "te maken of liever aansienlijke qualiteiten te verkrijgen" in deze reden van ontevredenheid zou geven over het gebruiken van een ander persoon dan diegeene die "'t werk soo favorabel, "so possibel en so uytvoerlijk stelt, dat men absolut aan geen "ander de uitvoering van dat werk kon opdragen."

Hierom stelt hij de verqadering voor, dat men P. vooreerst 10,000 Rijksd. aan de te 'Timor het meest gewilde specie zou ter hand stellen, om daarvan zoodanig gebruik te maken, als hị het best zou oordeelen, mits ons daarvan behoorlijke verantwoording te doen.

Voorts 100 Europeesche militairen onder wakkere en vigilante officieren, benevens 200 Inlandsche militairen, om daarmede en de hulptroepen van de Bondgenooten de zwarte Portugeezen onder bedwang te brengen, en meester te worden van de naar de beschrijving goud gevende rivieren van Belo, welk Rijk door dien Vorst an de Nederlandsche Compagnie was afgestaan, onder deze voorwaarden, "dat men haar beschermen sal tegen "alle die geenen die haar vijandelijk zouden willen attacqueren, "als bijsonders de swarte Portugesen, welkers lastig en onver"dragelijk juk van dwingelandị (NB.) sij onmogelijk langer "kumnen verdragen."

Men moest dus hen eerst verlossen en dan aan het project van goud zoeken begimnen "om dus 't wesenlyjke van 't sujer"ficiele (in hoe verre den ondergeteekende 't gantsche werk "nog maar erkent) zal kunnen onderscheiden."

Om dadelijk aan het werk te kumneil gaan, zouden er nog 206 Compagnies slaven van beiderlei kumne, bij dienen gevoegd te worden, van iedier de helft, allen voor een geheel jaar van kleeding en mondbehoeften voorzien. 
Aan P. diende voor den tijd dat hij zich daar ophield over bet kautoor te Timor het gezag te worden opgedragen, zonder onderscheid van zaken, echter met deze bepaling, dat hij buiten het goud zoeken, wasschen, ziften of oprapen, "waartoe immers "hope gegeven werd, ja selver tot stukken van heele en halve "vuysten., geen andere daden zou mogen plegen als aan een onderschikt Opperhoofd werd toegestaan. Hij moest derhalve affeggen "de gedachte van 't caracter van Commissaris" en aldaar ten minste een jaar verblijven, en tot nadere order van de Regeering.

Hij Direct-Gener. zou zich over het goud, dat onder de overgebrachte stukken gevouden zou hebben moeten worden, doch niet gevonden was, niet verder uitlaten, maar het verder onderzoek der koperbergen, die al in de vorige eeuw "en vervolgens "nu en dan ook in dese, dog sonder gevolg, is voor den dag "gebragt" voor zijn aandeel overlaten aan P. en zich bij provisie dezen aangaande refereren aan het voorm. bericht van den Eersten Opperkoopman Senff, waarin de ware gesteldheid van het een en ander was opgenomen.

In het breede tracht de Direct.-Gener. nu te ontzenuwen de klachten van $P$. over de naar Timor gezonden en voor geschenken bestemde goederen, doch die ook tegen betaling konden worden uitgegeven. ( ) a. had P. eenige van die goederen expres van de Koninkjes opgekocht 1 en naar Batavia gezonden, om, zegt de Direct.-Gener., "Lw Hoogtid. met trouw verpligte eerbied "te toonen, hoe trouweloos en onbeschaamd d' Ed. Comp. van "sommigen harer besoldelingen wierd gedient, en dat hij seer "ootmoedig versogte, dat $\mathrm{Uw}_{\mathrm{w}} \mathrm{Hoog} \mathrm{Ed}$. de coedheyd mogten "gelieven te hebben, sijn geteekent berigt daaromtrent te door"bladeren, en dese terug gesondene goederen daarmede te ver"gelijken, op dat evident en met verwondering mogte blijken "hoe ontrouw, eerloos en onbeschaamd dese dienaren humne betaals"heeren en hare Bondgenooten behandeiden, want dat niet alleen "dese Bondgenooten bedrogen wierden, maar dat 't aan deselve " ook een donkere en swarte idee gaf van de grootheyd en edel-

1 Het waren: 1 Hoed met pluimen te Batavia aangerekend. . f 24

1 gouden kriel?. . . . . . . . . . . . 48

1 rol Macauwsche stof . . . . . . . . . . 72

1 chits roode srond met groote bloemen, doch was 
"moedigheyd der Comp. en dat NB. om een Kleyn Winkelıer "te verreyken."

P. had met zijne aanmerkingen, zegt de Direct.-Gener., wel te huis mogen blijven, "die inderdaad meer precipitant, als "bondig sijn" en. waaraan hị P. echter zoo eene bewonderingswaardige inieiding geeft, "wanneer hij o. a. in 't begin van die "periode bị sijn rapport segt: dat hịj met 't verhandelde soude "hebben kunnen sluyten, indien nict de hoog gaande schelme"rïjen, die so op Batavia als elders gepleegt wierden, en de "matuurljjke adversie die hij tegen sulke ontrouwe dienaren hadde, sijune penme noodperste "eenige staaltjes dier schelmen aan Uw HoogEdelh. te openbaren."

Want iemand die hem niet kende en dit las, zou immers niet kumnen noch mogen twijfelen of hij was een man die de eerlijkheid en trouw in persoon verbeelde; die de Compagnie lang en in verscheiden ambten gediend had en die den dienst niet alleen grondig kende, maar ook veel kantoren had bezocht en zelfs de geheimste practijken wist, die daar als op Batavia tot nadeel van de Compagnie en hare bondgenooten gepleegd werden.

Als men echter de zaak van wat naderbij beschouwde of bij het licht zag, dan verviel die hooge ophef ten eenemaal tot niet; want hij was immers nauwelijks ergens anders geweest dan op Batavia, en al was dit ook zoo, dan had zijn vorig "metier" van ziekentrooster en vrijburger hem geen gelegenheid kumnen geven den dienst vau de Compagnie te leeren kennen, en bijgevolg kon hij niet weten wat op Batavia, veel minder wat elders onging.

Hij sprak bovendien niet met omzichtigheid of in bedekte termen, zooals ten minste de eerbied voor zijne hooge gebieders wel vereischte, maar hij verklaarde ronduit in algemeene bewoordingeu, "dat de E. Comp. schelmen in haren dienst heeft; hịj makte "sulx vervolgens in specie applicabel" op den Kleiu Winkelier te Batavia, en wanneer hij tot slot daarbij voegt, "dat de Comp. en hare bondgenooten bedrogen worden en dat "NB. om den Kleyn II inkelier te verryken", zoo betrok hị daarmede hen, aan wien de administratie of het toezicht over den Klein Winkelier was toevertrouwd, even alsof die willens en wetens zuike "hoog gaande schelmeryen en bedriegeryen " toestonden.

Doch waarmede zou P. dit zeggen kunnen goed maken? Hij kon niet eens bewijzen dat de Klein Winkelier "presumtief" de 
Compagnie grootelijks had benadeeld, gelijk hij Direct.-Gener., zooals hij reeds had aangetoond, en echter durfde hij de Hoofdadministrateurs beschuldigen dat zij met den Klein Winkelier zamen deden.

Dit was eene stoutmoedigheid, die nauwlijks hare wêerga vond en die zoo onbeschaimd op het papier was gebracht, dat hị wel wilde bekennen dat, zoolang hij de Comp. had gediend hem nooit dergelijks bij eenig geschrift was voorgekomen.

Het was onmogelijk dat hij Direct.-Gener. zich niet grootelijks zou getroffen gevoelen over het affront dat hierdoor de Opperkooplieden van het Kasteel als Hoofdadministrateuren in hun aubt en eer aangedaan werd; waarom hij zich dan ook verplicht achtte, hen volgens billijkheid te rechtvaardigen en de Regeering te verzoeken, dat aan P. werd gelast bewijzen van zijne gezegden bij te brengen, en bij gebrek daarvan mocht worden "gecorrigeert", zooals hij bevonden zou worden te verdienen, dewijl hij Direct.-Gener. al te wel overtuigd was, dat sedert hij de eer had gehad, zijn tegenwoordig ambt te bekleeden, omtrent de geschenken alle mogelijke attentie was gebruikt ten einde daarover klaciten voor te komen.

Was P. maar eenigszins binnen de palen van redelijkheid gebleven, of dat hij Direct.-Gener. zich kon overtuigd houden dat hij P. hier oubedachtzaam en dus niet met opzet was te werk gegaan, hij zou de zaak niet zooveel waard achten om hunne Hoog Edele daarinede lastig te vallen. Maar daar iedere regel dien hị daaromtrent had geschreven, "geenszins los " maar met voorbedachten rade was ter nedergesteld, zoo mocht hij het niet onopgemerkt laten voorbij gaan; te meer het niet zoo zeer uil liefde tot de waarheid als wel om "sijne eygene inbeelding "wat te vleyen en sig selve met de phariseën boven 't gemeene "mensdom stellen, gelijk geschied is", want anders zou hịj zijn eigen inborst zoo niet geprezen en anderen naast zich veracht hebben.

Hị zou ook geenszins tot slot van die "deftige harangue" zich in dezer voege hebben uitgelaten:

"Dat al schoon hij versekert was, dat haar Hoog Filele na "lecture van sijn rapport, na derselver gewoone equiteyt, die "onmrogelijk zulke schelmstukken kumen tollereren, daarin souden "voorsien, hij egter niet in gebreke hadde willen blịven, daar"omtrent, ook 't syne met gnustig belieren te contribueeren."

Want hierin toonde hij immers duidelijk dat hij aan de te Volgr. I. 
attentie der Regeering wel niet twijfelde om de quaade practycquen harer onderhoorigen te ontduiken en te beletten, mar hij wilde echter de eer niet aan haar alleen laten, maar zich ook een gedeelte daarvan toeëigenen, en opdat zijne redenen zooveel te meer ingang mochten vinden en tevens eenigszins gewettigd schịnen, besloot hij alles met deze les, die hij op een meesterachtigen toon daar nog bijvoegt: " dat geene oogen te veel 't opzigt "kunnen hebben om de schelmerijen tegen te gaan."

Wat nu de geheele zaak van de negorij Lando betrof, moest de Direct.-Gener. alvorens hij dienaangaande nader zijn advies ten principale, buiten hetgeen hij deswegens in de zitting van den 24 September 1756 verzocht had, dat aangeteekend mocht worden, aanhaalde 1, vooraf laten gaan eenige opmerkingen, die

1 In de Vergadering van dien dag werd o. a. behandeld de vraag, hoe diende te worden gehandeld ten opzichte van de door P. "als «rebellige en krijgsgevangene en om die redeıen, volgens de Lijst der "behaalde voordeelen als slaven opgezondene Landonezen enz.» Na eenige deliberatiën werd bij meerderheid van stemmen ${ }^{*}$ besloten ze voor vrije menschen te verklaren. Dit advies van den Directeur-Generaal luidde als volgt:

1. Dat zijn Edele de verrigtingen van P. in cas subject improbeerde, nademaal denzelven niet gekwalificeerd is geweest bij sijne Instructie om zoodanig te handelen, bij gevolg tegen de Instructie der Regeering heeft te werk gegaan, omtrent het als slaven overzenden der door hem krijgsgevangen gemaakte Landonezen.

2. Ter zake hij de Tommongongs zonder verder onderzoek heeft laten arresteren. niettegenstaande hij zelve bij zijn overgezonden rapport bekent, bij onderzoek bevonden te hebben, dat hunne klachten in waarheid bestonden, en dus daardoor niet alleen gelegenheid heeft gegeven tot de vlucht van den wettigen Prins, maar bovendien willens de grondslag heeft gelegd tot de vervolgens daaruit ontstanen openbaren opstand.

3. Dat dewijl de Landonezen nadat hen het pardon op eene publieke wijze door het laten waaijen van de witte vlag was aangekondigd, de wapenen reeds nedergelegd en zich overgegeven hadden, het uyt dien hoofde niet overeenkwam met de waardigheyd van 't uyt name dezer Rege ering door meermelde Commis aris zoo plegtelijk gegeven woord van vergiffenis, zijn Edele dierhalie on der gevolgen wille van advis was, dat alle die menschen, onder den naam van krijgsgevangene slaven, benevens de 300 stuks welke aan de gemagtigdens van veelm. P. ter dezer Hoofdplaats zijn overgezonden, mitsgaders alle anderen die particulier nog zouden worden angebragt, voor vrije persoonen behoorden verklaard te worden

* De Gouverneur-Generaal stemde tegen en met hem de Raden van der Spar, de Klerk, van der Velde en van Rheden. Fóor de lirect-Gener. de Raden van der Waaijen, Hooreman, van Hoheudorf, de Nijs, van Basel en van Ricmsdijk. 
betrekking hadden op het genoteerde bij het rapport van $\mathrm{P}$. en wel:

1. Dat de Landonezen driemaal tegen den Regent Geolima zouden hebben gerebelleerd omdat zij haren wettigen Regent niet hebben gehad.

Wie de wettige Regent zou zijn, kon hij niet bevroeden, ten ware dat het mocht wezen de in het jaar 1737, als van alle de Landonezen verlaten zujnde gedimoveerde Angi, dan wel een zijner kinderen, in wier eerste plaats, die alstoen onmondig was en door zijn oom den bekenden Termanos Regent Doumano geregeerd werd, weder tot Regent, op het speciaal verzoek van de Landoneesche Grooten, en de Timoreesche Vorsten en al de Rottineesche Grooten en Regent van Lando was verkozen, de hiervoren genoemde Geolima : die verklaard werd te wezen de ware Regent van Lando, volgens den inhoud van het schrijven van Timor van den 7 October 1737, dat door den Direct.-Gener. werd overgelegd. Benevens eene aanhaling in antwoord op dit schrijven van Timor, door de Hooge Regeering van den 20 Februari 1738 , waarbij die verkiezing werd goedgekeurd, zoodat niet kon worden gezegd, hij onwettig in het Regentschap getredeu of als voogd over den onmondigen afgezetten Regent de Regeering te hebben aanvaard. Dit werd echter alzoo gevonden in het rapport van P., even zoo dat deze zoogenaamden Prins Regent meerderjarig was zonder dat ergens ziju naam werd genoemd, dan aan het einde bij de wederherstelling van de Negorij Lando, waarbị hij Bani zoude genaamd zịn.

Wamneer hij Direct.-Gener. dezen Prins Regent voor den voormelden Angi of zijn zoon bleef aanzien, vond hij dat deze, dan wel weike Prins het ook mocht geweest zijn, zoodra twee Tommongongs op de klachten van Geolima, "geadsisteerd" met de voorspraak van al de Rottineesche Regenten, benevens die van hunne Hoofden gearresteert waren, met ziju jongeren broeder naar Lando, tegen de vermaning van P. gevlucht was en met zijn aanhangers, die volgens de getuigenis van P. de sterkste

en bij provisie ten koste van P. aangehouden, om bij het toelaten der mouson naar haar Land terug gezonden te worden, ten eynde dus doende het crediet der Comp. staanie te houden, en met een te doen blijken dat de intentie geenszins is om vrije lieden in den slarschen strat te stellen; hebbende zijn Edele wijders verklaard zich ten dezen subjecte nader in geschrifte te zullen declareren. 
waren met de factie van den Regent Geolima "asm den anderen ngeraakt zijnde, door 't zwaard onder hare gehoorzaamheid gebragt "heeft" de overige Landonezen, die de Direct-Gener. beschouwde eu zeker stelde de aanhaugers van Geolima te wezen.

Daar de aanhangers van den zoogenaamden Prins Regent te beschouwen waren als de aanvallers van die van den wettigen Regent Geolima, zoo was de vraag van den Direct.-Gener. welke redelijkheid of billijkheid er dan bestaan had om de aanhangers van den Regent Geolima, die aangevallen en door de Tonmongong ten onder gebracht waren, krijgsgevangen te maken en hen van humme Tanden te ontzetten, ja wat "enormiteit " lag er niet in opgesloten, dat men den Regent Geolima onder de minste Landonezen op een vaartuig geplakt en naar Batavia had gezonden om tot slaaf verkocht te worden; zonder dat daarvan bij de brieven van Timor verzonden, het minste gewag was gemaakt, daar hij bij de onlusten op Lando op Coepang was geweest en derhalve datrin geen het minste aandeel had gehad. En om de zaak of persoon van Geolima gevaarlijk te maken, waartoe men neer grooten lust scheen te hebben gehad, beschuldiggde men hem, dat hị zich met de zijnen en die var de Negorijen Bulba, Batoe-Isie en Boeay dikwijls zou hebben getracht aan de Portugezen te onderwerpen.

'T'ot staving hiervan bracht men bij de beantwoordde "interogatoria " van de twee op de klacht van Geolima gearresteerde Tommongongs, zoomede eene verklaring van den Regent van Timo op het eiland Sawoe gelegen. Volgens het gevoelen van den Direct.-Gener. kon en mocht men die niet aannemen, daar de eerstgeuoemde zijne vijanden waren en de laatste een vriend van hen; men kon dit opmaken uit den inhoud zijuer verklaring, dewijl hij Nay Latsa, een dier Tommongongs, den wettigen eigenaar van Lando noemde en Geolima den naam van "usurpateur" van Iando gaf; het tegendeel hiervan was grenoeg bewezen.

Daar dus het tractaat met Geolima aangegaan door hem noch de zijnen verbroken was, gelịk hị daarvan werd beschuldigd, daar hij niet eens bij de troebelen op Lando, maar wel te Coepang was geweest, zoo was hị volgens het gevoelen van den Direct.-Gener. "zeer ten onregte van rebellie en verraderij betigt en derhalve zeer onregtınatig en onregtvaardig gekasteyd."

Nog was het den Direct. Gener. voorgekomen: 10 dat door P. aan dis Tandonesen zonder onderscheid op eene plechtige wijze pardon was verleend, en ten $2^{\circ}$ dat, om ze op eene vreed- 
zame wijze van daar te krijgen, "men haar gepromitteerd heeft "eane absolute behoudenisse van haar vrijgeboren staat," terwijl men echter naderhand getracht had hen voor slaven te verkoopen "om een winst van $f 139,220$ was het mogelyk te vertoonen "en daardoor om naam te maken" en wel in dezer voegen:

$\mathrm{O}_{\mathrm{p}}$ Timor waren 1145 krijgsgevangenen, als 1000 tegen 20 en 145 voor 15 Rds. als een winstpost bij de boekeu reeds ingenomen met.

f 65,220

die de Direct.-Gener. vermeende dat afgeschreven moest worden.

Bij de rekening door $\mathbf{P}$. opgemaakt, werd het Comptoir-Generaal ten goede gebracht, hetgeen deze menschen op Batavia meerder waardig waren dan op Timor waren ingenomen, en bij de boeken voor ieder stellende $35 \mathrm{Rds}$. of in het geheel $60 \mathrm{Rds}$, daar doorgaans de beste Timoreesche slaven ten hoogste 60 Rds. konden halen, maar meest op 50 , 40 , 30 te staan kwamen, en dan nog volwassenen menschen; waren daarentegen ouder deze zoogenaamde krijgsgevangenen, eene menigte oude afgeleefde menschen en kinderen geweest, terwijl een goed aantal voor hume komst te Batavia overleden waren "monteerende deze meerdere gestelde waarde $N$. . . . . . . . . . . 70,000 Of te zamen . . . . $\bar{f} 139,220$

Zoodat ten gevolge der gestelde opmerkingen en ter zake dat de Tandonezen die de aanhangers van den wettigen Regent Geolima uitmaakten, niets anders hebben gedaan, "dan "defensief geageert tegen den zoogenaamden Prins Regent en "sijne complicen, en mogelijk op de aannadering van de Militie "met de anderen te zamen de retraite genomen hebben na de "bekende klip of elders, zonder zig aan rebellie tegen de Comp. "te hebben schuldig gemaakt", de Direct.-Gener. van advies was: dat de Regent Geolima behoorde te worden hersteld in zijne door de Regeering verkregen waardigheid van Koning of Regent van Lando, en net hem weder naar Timor te zenden allen die hem waren trouw gebleven; daarentegen niet alleen op Batavia aantehouden en onder de Bataviasche Inlandsche Regenten te verdeelen, om in hunne cigene behoeften te voorzien, de volkeren van de partı̣ van den zoogenaamden Prins Regent; maar ook naar Batavia te laten opkomen, de beide Tommongongs, die door 
P. waren gearresteerd doch daar waren gelaten, met den nieuw verkooren Rijksbestierder van Lando; zijnde een zoon van een dier beide Tommongongs, zoowel als den nieuw verkooren Koning of Regent «als het subject sijnde dat den eersten steen "tot het werk van den opstand gelegt en voortgezet heeft ina "den inhoud van het rapport van den Opperkoopman P., en dus "nevens de zoonen der beyde Tommongongs, die volgens ver"zekering op het arresteren van hunne vaders ten eerste naar "Lando overgegaan zijn, aangezien moet worden voor 't origeneel "werktuig van de geheele omwenteling van Lando, de jammer"lijke einden van vele van hare Landgenooten en d'aigreur die "notoir de Timorse Koningen en Regenten tegen de Comp. "moeten hebben opgevat, uythoofde van de ongehoorde en on"billijke procedures tegen meerm. Geolima en sijnen annhang "gehouden; na dien niet valideren kan de ten sijnen laste her nvoorwaarts gemelde twee verklaringen, die ingewonnen schijuen "te zijn, om de zaak eenige glimp of met vrij wat drift geexecu"tee rde sentimenten hier door een andere gedaante bij te setten."

Dewijl Liphao maar was en sandelhout scheen voorttebrengen, een zeer armoedige plaats was en ook niet veel goederen zou kunuen slijten en dus geen handel van eenige beteekenis veroorzaken, en men met dit alles zich zoude moeten bemoeien de "nu de verleende tituls van den Opperkoopman P. Hoog"waardige genad (ige) Bisschoppen en Eerwaarde Paters, mits"gaders trotse hoogmoedige Portugesche Militie, met haar "transport van Macao na Liphao te sorgen," — was de Direct.Gen. van gevoelen het beste te zijn on vau die vaart af te zien en desmogelijk aan particulieren over te laten, omdat een mindere inkoopsprijs van het was (het sandelhout als niet gewiid, ging hij stilzwijgend voorbij) niet zou kunnen opwegen de ongelden van equipagie, victualij, soldij enz. die men daarom zou moeten doen.

De onbepaalde kwalificatie om den Koning van Coepang bij de eerste "figuur" naar Batavia op te zenden, zoo vermeende hij dat daaromtrent eene nadere bepaling diende te worden gemaakt, en het Opperhoofd aan te schrijven om daartoe niet over te gaan, dan in de alleruiterste noodzakelijkheid. Den Groot-Majoor de Wend diende een extract uit de memorie ter hand gesteld te worden, ten einde zich te verantwoorden "over de accusatie dat " hij zeker uyt nijd, en was 't mogelijk daardoor eene zoo ge- 
" wigtige expeditie te doen mislukken, hem P. heeft mede gegeven, " een honderd ongedresseerde zieke en kreupele soldaten." Daar de Gecommitteerde tot en over den Inlander Freijer was overleden, was het niet mogelijk te onderzoeken in hoever het met de waarheid overeenkwam, met het door P. al verder genoteerde ten aanzien van de Inlandsche Militairen, namelijk dat zich onder de zoogenaamde 60 Balinezen, 50 oude en door kwalen geheel ongeschikte Javanen zouden hebben bevonden.

Onder de afgekondigde Plakkaten door P. was er den Direct.Gener. een voorgekomen, waarbij de bepaling werd gemaakt, wie een degen en rotan te gelijk, en wie maar één van dit handgeweer alleen zou mogen dragen; het kwam hem voor dat dit plakkaat als te "belachelijk moest ingetrokken en vernietigd worden."

De Direct.-Gener. zou, ofschoon hij niet onopgemerkt kon laten, dat de Opperkoopman P. zich zelf tot Commissaris over alle de zaken van 'Timor had opgeworpen, daar hị alleeu tot het veruieuwen der contracten enz. was gezonden, dien stap, hoe vrijpostig die ook was, "om eenige goede schikkingen en "oogmerken die hij in deze of geene pảssage had gehad", voorbijgaan, en tot slot van zijn advies zeggen: dat hij vermeende dat het al reeds te Batavia betaalde voor 18 stuks op vrije voeten gestelde Landonezen, ook de vracht van 761 hunner, bedragende te zamen $1887 \mathrm{Rd}$. volgens eene bijgevoegde notitie te Batavia, ten laste van Timor diende afgeschreven en op dat kantoor te worden overgebracht, en dat het Opperhoofd Beynon zich moest verantwoorden op al hetgeen bij het rapport van P. ten zijnen laste bekend werd gesteld.

De Direct.-Gener. van der Parra leverde tevens een protest in tegen den gedeeltelijken inhoud van het contract of acte van verbond en voorwaarden door P. uit naam en van wegen de Hooge Regeering, aangegaan en gesloten met de gezamenlijke Kouingen en Regenten van Timor op den 9 Juni 1756.

Bij de "resumtie en examinatie" van dat contract, had hij met de uiterste ontstichting en verbazing ontwaard, dat P. op eene alle regelen van voorzichtigheid en gevoeglijkheid te buiten gaande, ja ten eenemaal strafbare wijze zich had uitgelaten over de Engelsche, Fransche, Spaansche en Portugeesche natiën, tusschen welkers gekroonde, Hoofden en der Staten Generaal, der Vereen. Nederlanden, (volgens de jongste berichten) eene gewenschte en dierbare vrede bestond. Voornamelijk had hij de Fransche, Spaansche en Portugeesche natien met de aller- 
foeilijkste en haar van de hoedanigheid der redelijke schepselen geheel ontbloote titulatures bekend gesteld; zoo las men o. a. bij art. 5 van dit verbond:

"En aangesien het wereldkundig is en de droevige onder"vinding der gesamentlijke Koningen en Regenten ten meermalen "heeft doen sien en met overgroote smarte gevoelen, hoe tirannelijk "de blanke Portugesen so wel als de Swarte ditos, met de arme "volkeren in dese gewesten omspringen; wat insolentiën, wat "vexatiën en extorsiën so niet al aan hunne onderdanen hebben "gepleegt en nog dagelijks plegen, deese door 't opleggen van "ondragelijke lasten tot op 't gebeente uytmergelen; de voor"maals gelukkige landstreken, van te voren gelijk als opgepropt "met reyke en magtige bewoonders, sijn door dese wreede "monsters en verscheurende roofdieren ontvolkt, in barre woestijnen nen onbewoonbare wildernissen verandert; en hoe barbaars en "onbarmhartig de Spanjaarden, een volk ontbloot van alle men"schelykheyd, de ellendige, van haar door vuur en swaart gesub"jugeerde natiën, geplaagt, onderdrukt, mishandeld en eyndelyk "met de hevigste tormenten om 't leeven gebragt hebben, kunnen "de geschiedenis en reysboeken met schrik en afgrijsen getuigen.

"En wat een schweep en geesel voor 't menschdom de wreede "Franschen syn, ondervinden alle de geene welke genooddwangt "sijn 't juk hunner dwinglandij te dragen, synde derselver magt "en grootheyd op de puynhoopen van't menschelyk geslagt gebouwd "en gegrondvest; haare onderdanen alles afnemende wat se besitten, " om sig door derseiver sweet en bloed te verrijken en groot "te maken; vervoerende den geenen die se overwinnen naar "andere ver afgelegen naare, yselijke, sterile en koude gewesten, "alwaar se op meer als onmenschelyke wyze ter dood loe ge"plaagt werden. Wat verwoestingen, wat wreedheden, wat ge"weldenaryen, wat onderdrukkingen eyndelijk deese bloeddorstige "natie in alle de bekende werelds aangerigt en uytgevoerd heeft, wis geen tong vermogend, geen woorden schrijfelijk genoeg om "de knevelaryen en moordadigheden dier natie naar vermogen uyt "t te drukken. Volkeren en natien die nooyt 't juk van derselver "jammerlijke en drukkende dienstbaarheyd beproetd hebben, "kumnen sig geen regt levendig denkbeeld formeeren van de "rampsaligheden, die dit onmenschelyk gebroedsel, aan Gods "schepselen hebben doen gevoelen.

"Natuur en reden moeten dierhalven een volk afschrikken nom ouder 't gezag van sulke barbaren te sugten, die egter 
"door een verfoeylijke Statkunde, door een bedriegelijke en "geveinsde vleyerij onder schijn van 't welwesen van zie' en "zaligheyd te betragten, de onnosele menschen weten aan sig "te lokken, en deselve in hun net hebbende, met een kwellend "juk van slavernij en onderdrukking onophoudelijk beladen, en "van 't genot eener vryen godsdienstoeffening soowel als eener "dierbaren vrijheyd beroven, die dog alle menschen natuurlijk "toekomt en sonder 't grootste ongelijk niet kan ontvreemt "worden. Volkeren die van dat natuurlijk regt gauderen, moeten "sig noodsakelijk onder bescherming van eene natie begeven "die sulke overheerlijke voorregten door eene vrije Regeering "genieten, alwair de dwingelandij verbammen, en daarentegen "het regt op den troon sit te blinken, als een heldere son, "regt doende sonder onderscheyd van rijk en arm, biank of "zwart, in. of uytlander, Koning of onderdanen, mitsgaders "den ?aatsten door wetten geregeérd word, die hem in 't bij"sonder, en de gantsche matschappij gelukkig doen leeven.

"Dit bijsonder voorregt nu, om door het genot der vrijheyd, "landen en volkeren te doen floreeren, de bewoonders gelukkig nte maken en in humne besittingen sonder vreese gerust en "voylig te doen leven, moet men alleen bij de vrịe Hollanders "zoeken, dewelke altoos een gedrag vol van opregte en nobele "gevoelens, omtrent al de natien en volkeren onder hare bedie"ning staande, getoond hebben, als geen onderscheid makende "tusschen de swarte en blanke natiën, gelijk wel voormelde "natiën soomede ook de Engelschen en meer andere doen, met "altoos de haare gelijk te geven, de arme swarten onderdrukken "en niet als humne medemenscien maar veel erger als honden "tracteeren."

Zoo had de Direct. Gener. die de eer had te wezen het eerste lid van de Hooge Indische Regeering, "bij gevolg ook of "vóor de ratificatie, alteratie of disapprobatie, zich verpligt vond "te verklaren, (en) zich genondzaakt gevonden te protesteren tegen "alle schaden, nadeel, verantwoording of wat dies meer zij, die "uit de voorschr. reprochable, zoo niet strafwaardige conduite "van geciteerde Opperkoopman P. in cas subject gehouden, in"dertijd zouden kunnen voorkomen; nadien het genoemde con"tract een gemeen 1 schrift, en veele de nabij de Portugeesen "gezetene en de op Liphao haudelende Franschen niet onbekende "Koninkjes en Regenten, dus ten volle bekend zijnde, de appa-

1 Algemeen. 
"rentie bestond van niet buiten de kennis van hen en vervolgens "ook vau andere natiën te zullen blijven."

$\mathrm{H}_{\mathrm{ij}}$ liet het een en ander voor rekening en verantwoording van P. zonder zich direct of indirect aansprakelijk te willen stellen of in het allerminst verantwoordelijk, zoo nu als in het vervolg, voor dat geene dat daaruit zou kumnen worden geboren ten uadeele van den Nederlaudschen Staat en de Nederlandsch geoctroijeerde Oost-Indische Compagnie.

Het advies van den Raad van Indië van der Waayen, stemde, evenals dat van van der Spar, met dat van den GouverneurGeneraal overeen, evenwel met deze afwijking, dat van der Waayen op den 24 September te voren, onvoorwaardelijk stemde voor de vrijheid der van Timor overgekomen krijgsgevangenen; doch dit had hị gedaan met onvolledige keunis van den stand der zaken, daar hij slechts "deze en geene passagie uit het "commissoriaal rapport ter loops gelezen had"; nu, daar hij gelegenheid had gehad die documenten nauwkeuriger te examineeren, kwam hij gedeeltelijk daarop terug en verklaarde van advies te wezen, dat de krijgsgevangene Landonezen die vóor het toegestane pardon geapprehendeert en de zoodanige die tot "encouragement" der Regenten aan hen afgegeven waren "als slaven dienden te worden beschouwd" en voorts de op "Timor "verkochte krijgsgevangenen of slaven, zoo dezelve van laatstge"noemde zijn, voor wel en wettig verklarende", doch die geene voor vrij te verklaren die zich op pardon hadden overgegeven.

De veroverde wapenen zouden kunnen worden verkocht, en P. ter zake van zijn scherp en oneerbiedig schrijven schriftelijk worden gereprocheerd, terwijl voor het overige in zijne verrichtingen genoegen behoorde te worden genomen.

Ook de Raad Hooreman gaf aan de vergadering zijn advies in geschrift over, met verzoek dat het in de notulen van dien dag zou worden opgenomen.

Hij sustineerde dat $P$. niet gekwalificeerd was geweest iets verders uit te voeren dan dat zijne commissie hem voorschreef, namelijk: het vernieuwen der contracten, weshalve al het geene door hem verder was verricht voor zijne rekening en verantwoording bleef, te meer daar hij zich in alles als "een toomloos paard " had gedragen, en noch het Oppergezag der Regeering of der Heeren Meesters had erkend, doordien hij zijne commissie 
"generaal" had gemaakt en alles uitgevoerd wat maar in zijne heerschzuchtige handen opkwain, waardoor veroorzaakt was geworden dat hij veel "menschenbloed" had vergoten en de reeds door hem gepardonneerde Landonezen tot slaven verklaard. Dit had zoodanigen schrik onder de Vorsten te weeg gebracht, dat een ieder, "om niet mede denzelfden weg te gaan, in de poincten "bij de contracten vervat, maar hoe eer hoe liever had gecon"senteerd." Het was daarom te duchten dat die wel van geen langen duur zouden wezen mar bij de eerste gelegenheid weder verbroken, ja mogelijk wel met het gevolg dat zij kans ziende om van de verbindtenissen ontslagen te raken, zich onder de bescherming van een andere Europeesche mogendheid zouden begeven; buiten en behalve dat "deze contracten sịn opgevult "met ten uytersten irreverente, injurieuse, ledeerende en schen"dige expressiën tegen de Franschen, Spangerts, Engelschen en "Portugesen uitgebraakt, warover deze naar alle gedagten tegen"onsen Staat haar ressentimenten sullen toonen. Want hoezeer "deze contracten andersints als voordeelig souden kumen wor"den aangemerkt, zullen deselve door dat gedoente mogelijk zeer "duur komen te staan."

Zijn brief en rapport waren verder opgevuld met veel "vilipen"deerende uytingen" niet alleen ten aanzien van de Heeren Meesters, die der Hooge Regeering en "der inwoonders van "Batavia, maar zijne verwaandheyd en geabandonneerde vreeze "voor God selfs, ging zoo verre, dat hij zich niet ontzag in ziju "rapport profanelijk te zeggen, dat door 't aantrekken van een "schaapsvel, dan eens een leeuwevagt, dan wederom een tijgers"huyt en ook wel het ossenvel, sodanig een ieder intimideerde, "dat hị se soo pacificq als lammeren makkte, latende alles aan "syn uytspraak als of die godlyk was gedefereert."

Waarlijk een ongehoorde taal — zegt Hooreman - en schoone contracten die met geweld worden gemaakt; daar het toch bekend was, dat contracten niet konden bestaan dan wanneer de contractanten uit eigen vrijen wil daarin hadden toegestemd; "buyten nog dat desen man sig so verre te buyten gaat "dat sig als met goddelijke mayesteyt gelijk stelt, dewelke "mijner eragtens daardoor tén hoogsten werd geledeert."

Het kwam Hooreman voor dat, alvorens de Hooge Regeering daarop disponeerde, alle de stukken van P. dienden te worden overgegeven aan den Advocaat Fiskaal van Indië, om daarop te dienen van bericht. 
De Raad van den Velde was door ongesteldheid nict ter vergadering tegenwoordig, zoodat hij zijn advies in geschrift had ingezonden; nadat het voorgelezen was, werd het almede in de notuleu der vergadering opgenomen. Wij zien daaruit: dat hij reeds in de vergadering van 24 September te voren, adviscerde om de door P. opgezondene en zich op discretie overgegeven hebbende Landonezen tot slaven te verklaren. Toen had het aan den tijd ontbroken om alle de tot de commissie van P. behoorende stukken met attentie te lezen en te overwegen; dat advis steunde toen " alleenlijk op algemeene consideratiën van "de constante oorlogsgebruiken die de volkeren van Timor, "Celebes en meer Oostersche provintien steeds onderhouden, naar "dewelke de overwomenen, slaven van den overwinnaar werden" en van een menigte voorbeelden waarin de Comp. op eene gelijke wijze met die volken had gehandeld. Doch nu hij gelegenheid had gehad alle de stukken nauwkeurig in te zien en te overwegen, had hij behalve de reeds opgenoemde gronden, in de bijzondere omstandigheden "met en onder dewelke de overgave " der Landonezen sig toegedragen heeft, nog verscheyden nadrukwkelijke argumenten ontdekt die zijn gegeven advis ten vollen "justificeren." Hij zou deze zoo kort mogelijk voordragen.

De vraag of en in hoeverre het naar het uatuur- en volkenrecht geoorloofd was, de overwomenen in slavernij te storten, achtte hij niet noodig vooraf uitvoerig te onderzoeken, omdat er van een volk de reden was, dat dit voor een constant gebruik hield en als overwinuaar met ziju overwonnenen zoodanig te werk ging, " als overwonnen 't minste onregt in 't verlies der " vrijheyd gevoeld" sedert lang gewoon waren dit als een wettig en onvermijdelijk gevolg der overwinuing te beschouwen. Dit was dan ook de reden dat van Timor van tijd tot tijd lijfeigenen te Batavia ten verkoop werden aangebracht, daar het algemeen bekend was, dat daar geen slaven te koop waren dan die door de wapenen overwomnen en tot slaven gemaakt waren.

Van den Velde zegt: dat de Comp. tot nu toe nooit had geschroomd dit recht tegen die volkeren uit te oefenen; hij zou daarvan verschillende voorbeelden kunnen bijbrengen, doch wilde zich slechts bepalen, wat dienaangaánde in de laatste jaren op Timor had plaats gehad. In 1749 had het Opperhoofd aldaar vail deu Burg, een menigte van dergelijke veroverde volkeren gedeeltelijk op Timor voor slaven verkocht, gedeeltelyk en wel tot een getal vau 100 , naar Batavia verzondeu. Had de Hooge 
Regeering dit afgekeurd "of tegen 's Lands wetten en costumen " en ze ten nadeele van de Comp. voor vrije volkeren verklaard?" Thtegendeel, ze waren in het Ambachtskwartier geplaatst en vooral niet zonder voordeel voor de Comp. als slaven geëmployeerd geworden.

Zoolang men dus de handeling van den Commissaris P. uit dit gexichtspunt betrachtte en naar deze algemeene argumenten beoordeelde, dan had hị niets gedaan "als 't geene met de "Landswetten van dat volk, met de maximes en gebruyken der "Comp. en met derselver voordeel en intrest teffens volkomen " overeenstemt."

Maar wameer men alle bijzondere omstandigheden der plaats gehad hebbende gebeurtenisien onderzocht en beoordeelde, dan waren er nog vrij wat meer gewichtige redenen aan te voeren om het gehouden gedrag van den Commissaris "volkomen te approbeeren." 1. De oorlog of veel meer de opstand der Landonezen was in zijn eerste beginselen reeds onrechtmatig en strafwardig. Schoon hare grondstelling: "dat de doenmaligen "Regent Geolima slechts voogd Regent was van den minder"jarigen Prins en de Regeering aan hem bị deszelts Majore"niteyt moest overgegeven worden " aan en voor zich zelven inderdaad gegrond scheen; gemerkt eensdeels dat de Prins, voor wiens Regeering zij opkwamen, nog te jong scheen, anderdeels wanveer zịj sustineerden dat hịj meerderjarig en dus tot de Regecring bekwaam was, zij hare belangen geenszins door opstand, oproer, ooriog of geweld moesten handhaven, doordien de Comp. privativelijk den deciso van Regter van alle de verschillen, die tusscheu de Regenten opkwamen zijn en blijven moest.

2. Zoo waren zoowel de jonge Erfprins als de malcontentepartij gehouden geweest zich te voegen naar de beslissing van den Commissaris, die niet zonder veel omzichtigheid en wijsheid, mair na voorgnande deliberatiën met de Rijksvergadering en een rijp overleg gevolgd was. Vooral dewịl de Tommongongs niet onrechtmatig maar met recht als oproermakers en onrustige sujetten waren gearresteerd, en de Commissaris buiten dat alles aan den jorgen Erfprins "de maintenue en protectie der Comp." beloofıle, bijaldien hij de muitzieke partị der Tommongongs verlaten en zich gedurende zijne minderjarigheid vreedzaam wilde gedragen.

3. 'Loo iokte het verder gedrag van dien Prins en de muitzieke Landonezen een openbare vredebreuk uit, dewijl hij zich in het geheim naar Lando begaf en aldaar een formeelen opstand 
veroorzaakte, die door "de bloedigste en moorddadigste bedrijven" in eenen hevigen oorlog veranderde. 'Zoodat het landschap Lando, dat reeds driemaal gerebelleerd had en daardoor $\%$ ulk pernicieus voorbeeld aan de andere volkeren van die landen had gegeven, het nu als van zelfs sprak, het eene eclatante en met " de grootheyd haarer wanbedrijven overeenkomstige straffe te flagiteeren " omdat het zich in het oog van den Commissaris niet had geschaamd " tot zulke roekelooze vredensbreuk te vervallen."

4. Hunne kwade gezindheid had zich nog duidelijker vertoond, door zich met geweld en wapenen te verzetten tegen de door den Commissaris naar derwaarts gezondene krijgsmacht en die " trotselijk" het hoofd te bieden. Volgens het gevoelen van van den Velde zou niemand dit gedrag der Landonezen nog excusabel achtten of daarin de allerminste reden vinden om hen gratieuselijk te handelen, laat staan " communiceren."

Toen dit oproerig gespuis eerst op de vlucht gedreven en zich daarna op een ontoegankelịke rots, de Onverwinnelijke klip genoemd, hadden begeven, waar ze door 's Comps. macht ingesloten en eindelijk door hongersnood genoodzaakt ware:ı geworden zich over te geven, had de Commissaris "al vrij wat sagt met die rebelligeu gehandeld" door hun pardon te verleenen, mits dat zij zich op discretie overgaven.

Hij v. d. V. kon niet begrijpen dat zij door dit accoord het recht om hen tot slaven te verklaren zouden hebben verloren; dewijl het verleenen van pardon tegen de overgave op discretie, de overwonnenen niets meer beloofd dan lijfsgenade; de verdere voorwaarde "hing absolut af van de discretie van "den overwinnaar" die niet zoo hard kon zijn (mits men hun lịf en leven spaarde) of de overwonnene moest ze ondergaan. Men kon derhalve den Commissaris niet beschuldigen van het gegeven pardon te hebben geschouden, daar het alleen op discretie was gegeven "en dus niet op sig selfs of van dese conditie "afgesondert, maar in comnectie met dese bepaling moet verstaan "en begrepen worden." Integendeel had naar het gevoelen van v. d. V. de Commissaris in dit geval zeer "wijselijk" gehandeld, door hen voor slaven op te zenden. Vooreerst omdat het bepaald gevaarlijk was dit volk in hun land te laten, dat reeds zoovele blijken "in eene viermaal hervatte rebellie" had gegeven van humnen weerbarstigen en onrustigen aard, dat zelts geen der honingen van die landen hen onder zich dulden wilden : 
en ten anderen dewijl dit weerbarstig volk hierdoor op eene éclatante en tevens naar de rechten en gebruiken humner natie gegronde en "over sulkx bij dat volk als regtvaardig geoordeelde wijze" gestraft was geworden.

Behalve dit werd hierdoor tevens een genoegen gegeven aan de Hoofdkoningen van dat Land, die deze rebellen in de ten dien einde gehoudene Rijksvergadering die straf toewezen "door "dat de (omp. dese hare vrijspraken en gevoelens amplecteerde "en honoreerde", terwijl - e:ndelijk — dat volk na hunne overgave wederom mine gemaakt heeft tot het doen van opstand, die zonder het overwicht van 's Comp. macht niet zou zijn te bedwingen geweest "door welk attentaat 't selve verstaan moet worden selfs "alle voorgaande bedingen gevioleerd en sig allesins onwardig "gemaakt te hebben, van derselver voordeelen te gaudeeren."

Redenen van staatkundigen aard, die men vooral niet uit het oog moest verliezen, konden hier nog worden bijgevoegd. Vooreerst zoude men het respect der Comp. bij zoo veel Koningen en Bondgenooten merkelijk verminderen en bij hen een heimelijk misncegen opwekken, wanneer men het gehouden gedrag van den Commissaris op zulk een "eclatante" wijze improbeerde, omdat hij het besluit daartoe niet alléén genomen of ten uitvoer gebracht had, maar met aile die Kouingen en Landsgrooten te zamen in eene plechtige afzonderlijke bijeenkomst die de Groote Rijksvergadering uitmaakten. Aan die vergadering was tot nu toe verbleven het nemen van alle besluiten in inlandsche zaken "en van welkers decisie zulke zaken ook onwedersprekelijk afhangen." Wanneer men die rehellen, die door hen waren veroordeeld, hier weder vrijsprak, en zelfs als in triumf naar Timor terug wilde zenden, zouden zij zich ieder in humnen persoon en mallen in dese hare rịjksvergadering als een aanzienlijk lichaam geledeert en gehoond achten."

Welke nadeelige gevolgen waren er verder niet te duchten uit het herstel van een volk, dat, "viermaal gerebelleert hebbende" onschuldig verklaard en zelfs in spijt van welgezinde Koningeu en volkeren "gemainteneerd en gehandhaafd" werd?

Ook het belang van de Comp. bracht dit niet mede; want deze volgens hunne eigen wetten en door hun eigen volk in de hoogste en wettigste rijksvergadering veroordeelde en tot slaven verklaarde rebellen, hadden de Comp. ten minsten met 80 tot 100,000 florijuen verrijkt, genomen zelf* dat ze tot ongremeen lage prijzen verhucint of in 's Comp. slavendiensten 
gebruikt waren; daaruit zouden zeer gemakkelijk alle de onkosten van het vlootje, de gagien der dienaren en de afgezonden geschentken kunnen worden goedgemaakt; daarentegen had de Comp. nu dit "geboefte op den hals, dat doorgevoed sijncle, "hier niet als ondeugden uytvoeren, of naar haar Land keeren "en aldaar allerley ouheylen aurigten zal."

Dit waren de redenen die v. d. V. noopten om te blijven persisteren bij zijn advies op deu 24. September in deze zaak gegeven, en alsnog volhield, dat de op discretie overgegeven wettig en met recht van de hooge Rijksvergadering van Timor en onderhoorige landen voor slaven verklaard, en derhaive te recht door P. naar Batavia als zondanig waren opgezonden en gevolgelijk ook, dat ze ten voordeele van de Comp. als slaven verkocht of in haar dienst gebruikt behoorden te worden.

$\mathrm{Hij}_{\text {ij }}$ adviseerde verder, dat er een nauwkeurig onderzoek diende te worden ingesteld of P. $300 \mathrm{krijg}$ ggevangen Landonezen voor zịnn privé naar Batavia had opgezonden; mocht dit waar bevonden worden, dan kon men het niet "sonder eeu sensible cor"rectie" laten passeren. Was hij daaraau onschuldig, dan diende men eene "eclatante satisfactie" te nemen van degenen die de "eerste autheuren van zulke injurieuse beschuldigingen" zouden bevonden worden.

Het was dus billijk dat P. op die beschuldiging gehoord en toegelaten werd zic!ı te verantwoorden, te meer dewijl het de uiterste onbillijkheid zou wezen, dat de Commissaris "bij gebrek "van behoorlijke verantwoordigingeu, wameer teflens 't geresol"veerde van den 24 Febr, jl. ook ten opzigte van de door "hem overgesondene 300 lijfeigenen mogte stand grịpen, sulk "een aansieulijke schade lijden soude: so anders de voorm. 300 "slaven voors krijgsgevangenen Landođ゙ezen, maar particuliere "slaven wesen mogten."

Eindelijk nog kon v. d. V. niet verbergen, dat het hem zeer had ontsticht, dat P. na het zich in het uitvoeren zijner commissie zoowel naar wensch van de Regeering te hebben gekweten, bij zijn schriftelijk rapport "verscheydene vermetele en wan"voegelıjke expressiën tot disrespect van dese Regeering heeft "durven gebruyken, over dewelke hij behoorde serieus gerepro"cheert te worden; onvermindert nogtans 't welverdiende lof, "dat aan de getrouwe diensten van hem, aan de Comp. in sijue "commissien bewesen, niet mag geweygert worden." 
De Buitengewoon Raad van Hohendorfl had almede zijn advies schriftelijk ingediend. Hij vermeende dat de op Timor ontstane geschillen en beroertens voornamelijk waren toe te schrijven "aan den giemeenen man" en aan het gehouden gedrag van den Regent Geolima zelven. Dit zou uit het volgende kunnen worden opgemaakt: de eerstgenoemden hadden den Regent dikwijls klagender wijze te kennen gegeven, dat zij humnen wettigen Regent niet hadden, zekerlijk met dat inzicht om of vau den Regent Geolima zelven ontheven te wezen of om den Prins pupil, den zoon van den overleden Koning, tot Opper-Regent te hebben en niet den zoon van den Regent Geolima Dale, zooals het zoeken van Geolima scheen geweest te zijn.

Dit was echter geen reden genoeg, "alschoon ook al op hare "nadrukkelijke instantie weynig ofte geen reguard mogte ge"slagen sijn om tot zulke commotiën en publieke feytelijkheden "te komen." Want daarin had anders op hun behoorlijk verzoek dadelıjk door den Opperheer voorzien kumnen worden. Van Hohendorfl vermeende, dat in aanmerking genomen, "hoezeer "zulke verregaande stappen en nadeelige desseynen aitoos straf"baar zijn" hij daarom met alle recht "concluderen" mocht, dat allen die bij dat boosaardig voornemen waren blijven persisteren en van het aangeboden pardon geen gebruik hadden willen maken, met alle recht voor slaven konden worden gehouden, even zoo als daarvan vele andere voorbeelden waren aan te halen, zoo op Macassar, als elders om de Oost, ja zelfs in den laatsten oorlog op 'limor zelven ten tijde van den Resident van den Burg.

Voor het overige kon hij het gehouden gedrag van P. wel in zooverre goedkeuren, doch dat hy tevens "absolut verdient "een serieuse reproche; so met correctie over de grootsheden, "quade ja verregaande en zeer lederende expressiën of allegatiën " die bij zijne papieren te vinden waren en noodzakelijk door hem daaruit diende te worden geschrapt, "om hem dus te doen "bevatten, dat tussen een manier van denken en publicq seggen "of schrijveu een groot onderscheyd sij."

Bij moude verklaarde hij de krijgsgevangene Laudonezen die op pardon waren overgekomen voor geen slaven te kumne declareren.

Uit het schriftelijk advies van den Buitengewoon $R_{\text {aad }}$ vau Indië van Rheden nemen wij het volgende over.

In de vergadering van den Raad van den 24. September te voren had hij verhlaard, dat, dewijl de als krijgseyangenen 4e Volgr. I. 
door P. naar Batavia gezonden oproerige Landonezen tegen hunne wettige en van de Comp. over hen gestelde Regenten waren opgestaan, en zich door moord, roof en plunderen, mitsgaders oorlogen tegen de Comp. en derzelver wapenen hadden schuldig gemaakt aan rebellie, alsmede na dato op discretie zich hadden overgegeven, van gevoelen te wezen, dat deze Landonezen niet kwalijk behandeld werden, bijaldien ze ten voordeele van de Comp. als slaven werden verkocht, omdat het woord van pardon door P. meermalen aan hen gegeven tot niets anders strekte, dan alleen tot lijfsgenade, hetgeen zij als rebellen, volgens het recht des oorlogs hadden verbeurd en waaromtrent de Commissaris hen volgens zijne gedachten alleen het pardon had verleend.

Nu hij alle de stukken door P. overgelegd nawkeurig had geëxamineerd, had hij in die zaak om het belang, dat daarin voor de Comp. lag opgesloten, "van die importantie en aangelegenheid" bevonden dat hij vermeende zijn gegeven advies, dat alleen was ingericht op de vraag van den Gouverneur Generaal hoedanig met de overgezonden Landonezen moest worden gehandeld - nader met bewijsgronden te moeten staveu en de beweegredenen daartoe opgeven.

Doch voor dat hij hiertoe overging, kon hij niet voorbị ziju ressentiment "te betuigen waarmede de Commissaris ten sijnen "eygen opsigte voormeld rapport opvult en sijne heldendaden "ten papiere brengt, ja die de reverentie, en eerbied al te zeer "aankant settende dewelke hij dese Regering, als sijn wettige "overheyd schuldig is, over den inhoud van de hem medege"geven brief en instructie na Timor, mitsgaders over de con"tradietiën van onse orders in de hem medegegevene papieren "onthouden, schijnt te willen doleeren."

De geschetste en beloofde voordeelen door $\mathrm{P}$. in het verschiet voorgespiegeld, vermeende v. R. voor hersenschimmen te moeten houden, bijaldien niet bij het rapport ware overgelegd eene Staatsrekening, die aantoonde wat de Comp. bij die commissie had geprofiteerd 1 .

$\mathrm{Hij}_{\mathrm{j}}$ zou daarom van gevoelen zijn dat men P. in ernstige termen diende te reprocheren over het te buiten gaan van zijn

1 Hierop was volgens de marginale aanteekeningen van den Direct.Gener. mede vrij wat aftedingen. P. gat die op te bedragen $f 276,669$.v. d. P. vermindert die winst met.

Rest . . f 39,201 walvan nog ruim $f 19,000$ voor boeten enz. werden opgebracht. 
plicht, onder aanbeveling van in het vervolg omzichtiger te wezen cn de Regeering het behoorlijk respect te bewijzen, dat alle ondergeschikten daaraan als humnen vertegenwoordigden $"$ Souverain "te geven, schuldig waren, ter voorkoming van onse uyterste "indignatie en veel gevoeliger correctie in het vervolg."

Men zou hem verder betuigen, dat de Regeering met veel verontwaardiging onder het resumeeren van het contract met den Hoofdbondgenoot van Timor aangegaan ontwaard en gezien had, hoe hij P. tegen de absolute order en kwalificatie van de Regeering zich had durven vermeten daarin allerhaude "criante "lasteringen (art. 5) te laten invloeyen tegen verscheyden mach"tige Vorsten en Potentaten van Europa." Het was noch in de politie, noch in den handel noch in den dagelijkschen omgang toe te staan of iemand aauteraden met onwarheden en valsche opgaven zijn best en voordeel te zoeken, en zoodoende op de ruïnen van zijn naastens vollen verderf, de grondslagen vau zijn bedriegelijk fortuin te vestigen.

Hij oordeelde derhalve dat de Regeering - die nooit anders dan door gepermitteerde wegen en middelen de commercie van hare Heeren en Meesters zocht voortestaan, en die het niet onverschillig was op welke wijze dit doel te bereiken (!!) - P. diende te noodzaken om met eigen handen in de vergadering "alle de laesive en irriteerende expressiën uit 't art. 5 van dat contract doortehalen"; der Regeering wel expresselijk excuus te verzoeken over zulke verregaande emancipatiën en ondernemingen; en eerst daarua dat contract met de Hoofdbondgenooten te ratificeeren en zijn beslag te doen erlangen, opdat door een onvoorzichtige goedkeuring van dergelijke onhebbelijkheden de Regeering "niet incurreren in den hat van die hooge Mogendheden en zich subject maken een groote verantwoording van "onse Hoog Achtb. Heeren principalen."

Nadat dit was voorafgegaan, was hij echter van gevoelen, dat om het goede dat de Comp. van zijne verrichtingen (buiten hetgeen zoowel ten aanzien van de hoeveelheid Was en Sandelhout als den verminderden prijs daarvan reeds voor de Comp. geprotiteerd was) nog verder van de verbetering van den handei, aanwinst vau 's Comp. domeinen en het voorgestelde opvisscheu en wasschen van het goud, kon en mocht beloven, on hem P. te doen blijken het genoegen der Regeering wegens de goede diensten aan de Comp. bewezen en ter belooning daarvoor hem op te dragen het volvoeren van alle zijne projecten. 
Daar onder de besoigne over Timor den 24 Sept. te voren bij eenige Leden van den Raad 't geheele gedoente van P. was geïmprobeerd, zoo zou hij v. R. ter toets brengen alles wat hij vóor en tegen den Commissaris had kumnen ontdekken. Om hierin met orde voorttevareu begon hij met optemerken, dat, toen P. op den 20 Maart te voren op Timor was aangekomen, de beide twistende partijen op Lando - zijnde de een daarvan de Comp. Regent Geolima c. s. en de andere de Prins Regent en zijn Tommongon Nay Laftan - zich bij hem vervoegden. Na gedaan onderzoek ontwaarde P. dat de Tommongon Nay Laflia met den Prins Regent tegen hunnen wettigen en door de Comp. over hen gestelden Regent waren opgestaan, voor humne verontschuldiging hiertoe aanvoerende, dat die Regent een dwingeland en usurpateur was, die de Regeering — als voogd over den Prins Regent en oudsten zoon van den overleden Vorst van Lando en thans meerderjarig was - niet wilde overgeven aan zijn pupil, maar tegen de wetten van het land zijn eigen zoon Dale voor Regent wilde aanstellen.

De Commissaris, hoewel bij zichzelven overtuigd dat deze klachten meest met de warheid overeen kwamen, wendde zich zonder hiervan iets te laten blijken tot den Hoogen Landraad, "dewelke buyten alle disputen, de decisie over diergelıke zaken "vau Staat en ()orlog was aaubevolen."

Die vergadering stelde den Regent Geolima in het gelijk, en verklaarde de T'ommongons voor "schelmen" met verzoek dat ze mochten worden gestraft. De Commissaris, als de Comp. vertegenwoordigende, liet de T'ommongongs arresteeren, met verzekering desniettemin aan den Prius Regent van hem in de bescherming van de Comp. te zulien nemen, bijaldien hij voortaan de partij van de 'Tommongons wilde verlates. Deze, in plaats van hieraan gehoor te geven, begaf zich met ziju jonger broeder in stilte naar Lando, en brachtell daar door geweid van wapenen alles onder humne gehoorzaamheid. Hierop zoud P. den Onderkoopman Ringholm met zijne bijbebbende macht, ondersteund door het volk van de gezame!rjke Bondgenooten, tegen de opstaudelingen, verjoeg hen uit hun eerste post en dreef hen naar de Onverwinnelyke Klip die op order van P. werd geblokkeerd.

De belegerden, door den honger genoodzaakt, zonden daarop eenge gecommitteerden aan $P$. met verzoek om pardon, onder voorgeven niet tegen de Comp. maar tegen den overweidiger 
Geolima te oorlogen, die hun Tommongon Nay Taffa "al dikwijls een gouden ketting had aangeboden" om te consenteeren in het inroepen der Portugeezen. De Commissaris het een en ander in aanmerking nemende, stond hun het pardon toe, mits zij zich aanstonds op "discretie" overgaven. Zị die daaraan gehoor gaven, werden na aftrek van een derde, die aan de gezamenlijke Hoofd-Bondgenooten waren beloofd, aan boord gebracht en naar Batavia vervoerd.

$\mathrm{Nu}$ zou naar de gedachte van v. R. kunnen worden gevraagd, of een wettige Prins, die tot het bemachtigen van zijn rijk door een usurpateur en dwingeland, tegen de wetten van het land hem onbillijk ontnomen - oorlog voert, wel voor een rebel kan worden verklaard, "al schoon de Comp. zekerlijk door "een quade en verkeerde opgave van de Opperhoofden of Resi"denten aldaar sulk een Regent had geapprobeert." V. R. vermeende 't wel, omdat het aan niemand van de Regenten op Timor was geoorloofd zijn eigen rechter te wezen of zijn aanspraak, hoe billijk die ook was, door de wapenen te handhaven; en dit te meer dewijl het ook zoo werd begrepen door alle de Koningen en Hoofd-Bondgenooten van de 13 Vlaggen voerende negoryen, aan wien de beslissing over dergelijke zaken van belang was aanbevolen en waaraan ieder Regent subject was.

Hiervan strekte ook het bewijs en men kon er uit zien hoe kwalijk het werd opgenomen, hoe schielijk de gecombineerde macht en de snelle opmarsch der Bondgenooten met alle hunne troepen tegen de ondernemingen van den Prins Regent had plaats gehad, en die niet naar de vermaningen van $P$. had willen luisteren die hem een "voldoenende satisfactie" beloofd had.

$\mathrm{Na}$ het eindigen van den veldtocht en het overbrengen der meeste rebellen aan boord van de ter reede liggende schepen en vaartuigen, uit aanmerking van den Portugeesch gezinden Regent Geolima, waarvan P. inmiddels overtuigd was geworden, ontving de Ouderkoopman Ringholm van $P$. den last om te zien of het mogelijk was hem met list in handen te bekomen; dit gelukte; $P$. liet hem in het fort zetten en nam den 23 Augustus met de Hoofd-Bondgenooten in overweging: "om, "daar ḍe Prins Regent Bani, de oudste zoon en wettige erfge"naam van den overleden Koning en derhalven de echte preten"dent van de Provincie Lando was", hem wederom te herstellen en ter belooning van het ongelijk door hem geleden, tot Regent van Lando te verklaren. Na rijp beraad en volgens het nimmer 
hetwist recht werd hiertoe besloten, terwijl tevens tot zijn Rijkshestierder werd benoemd de zoon van den Tommongon Nay Laffa en hen uit de gevangen Landonezen 300 man tot hunne adsistentie toegevoegd.

On aan de geheele ompartijdige wereld te toonen "wat Regent "ziij voor diergelijke schelmachtige bedrijven hadde" en volgens het gevoelen van v. R. tot een blijk hoe gaame zij een beganen misslag wilden herstellen, zonden zij den Regent Geolima met zijne aanhangers mede aan boord, terwijl zij tevens allen voor slaven van de Comp. verklaarden.

Men zou - - zegt v. R. - hiertegen kunnen inbrengen en de vraag stellen: heeft de Prins Regent met de aanhangers van den Tommongon Nay Lafla deze rebellie begonnen? Heeft de Commiswaris met het arresteren van den Tommongon N̦ay Laffa den door de Comp. aangesteiden Regent Geolima in het gelijk gesteld, en de partij van, den Prins Regent door de wapenen ten onder gebracht en ze voor meineedigen, verraders en bondbrekers aangemerkt? Waarom werd dan toch de aanlegger zoowel als de verweerder, de schuldige met den onschuldige te gelijk het land uitgezet? en waarom werd den stichter van den opstand, namelijk den Prins Bani het Regentschap daarvoor tot een premie gegeven? De oplossing van alle deze vragen werd volgens v. R. gevonden in de kennis die de Commissaris met de vergadering van alle de HoofdRegenten en Bondgenooten van Timor had: dat Geolima was een trouwloos Regent, die den Tommongon Naỹ Lafla meermalen had aangezet zich aan de Portugeezen te onderwerpen en tot dat einde hem te vergeefs een gouden keten had aangeboden.

Een notoir blijk - vervolgt v. R. - dat zoowel de Hooge Regeering (door de misleidende voorslagen der vorige Opperhoofden, die Geolima als den wettigste tot het Regentschap hadden voorgedragen en die daarop was aangesteld) alsmede de Commissaris en alle Koningen en Hoofd-Bondgenooten bedrogen waren, en dat zij noch ten opzichte van de Comp. noch ten aanzien van de Hoofd-Bondgenooten hun eenigszins meer zouden vertrouwen. Ze wilden derhalve hier en voor de geheele wereld openleggen, dat zij zich in den persoon van Geolima hadden vergist " en "dat de tijd haar heeft doen ontwaren, hare misslag als tot "rüne van Land en Volk, mitsgaders nadeel van de Comp., "bij derselver eens opgevatte meening te persisteeren."

Y. R. nocmt dit "eecu sentiment, waarlijk niet van redelijke via free access 
"menschen maar ook van trouwe patriotten, die haar eigen eer, "Zoo 't een schande mag genoemd worden te bekeunen kwalijk "gedaan te hebben" dat bij huu zoo niet wordt begrepen "voor "t welzijn van 't gemeen sacrificeren en seer graag willen beken"nen quod errare humanum est."

Hiermede meende v. R. ten genoegen van de H. R. te hebben uiteengezet de toedracht der zaken op Timor, en dat P. niet alleen priva aucthoritate de gevangenen Landoneezen voor slaven verklaard en opgezonden had, maar dat dit volgens 's Lands wetten was goedgevonder en besloten door den Hoogen Landraad; bestaande uit hem Commissaris en al de Koningen, Hoofd. Regenten en Bondgenooten van Timor. V. R. zal nu overgaan om te onderzoeken of ze wel de bevoegdheid hebben gehad om zoodanige besluiten te nemen.

Het verbond of vredescontract, door P. uit naam van de Comp. ter eenre en uit de Koningen, Hoofd Regenten en Bondgenooten ter andere zijde gesloten, "demonstreert zulks ouweder"sprekelijk", terwijl het $10 \mathrm{e}$ artikel daarvan deze humne handelwijze. rechtvaardigde, behalve "dat het van algemeene bekendheid "was, dat immers geen natie op den geheelen aardbodem als "slaven geboren worden, buyten die geene welke zoowel in deze "als andere gewesten van dezulke afstammen en voortkomen "die tot slaven gemaakt zijn."

Worden alle meuschen vrij geboren, waardoor worden ze dan tot slaven gemaakt? V. R. antwoordt: door den oorlog, die in die gewesten de overwinnaars het recht gaf tot het goedmaken der oorlogskosten ze te verkoopen.

Waren niet alle "liuyshouders" zoo hier (Batavia) als op andere plaatsen in Indië daarvan getuige? en zouden de meeste ingezetenen van "deze coloniën", wier grootste kapitaal bestond in zulke door den ooriog tot slaven gemaakte vrije menschen, niet geruineerd wezen, bijaldien men aan dit "sistema" wilde twijfelen of het tegendeel daarvan staande houden.

Wat zou er uit die "tegenstrijdige positie" anders voortvloeien als een aaneenschakeling van moeilijkheden en een oorlog zonder ophouden. Zouden zij (de H.-R.) de Souvereiniteit van wettige vorsten, die het recht van leven en dood over huune onderdanen hadden, niet hierdoor den bodem inslaan en een gedurigen opstand van de lijfeigenen tegen hunne meesters veroorzaken? Had niet de Comp. zoowel in oude tijden als thans op dezelfde wijze met de overwonnen vijanden gehandeld? 
Waren niet de door den Admiraal Sinout in 1739 voor Goa veroverde volkeren en de in de jongste expeditie op Boeton verkregen gevangenen tot slaven verklaard?

Had niet de H. R. 1000 Boetonders in "recompens" gevorderd van den Koning, voor de "adsistentie of schuilplaats" aan den zeeroover Frans Fransen gegeven? en waren niet de door het Opperhoofd van den Burg in 1752 op dat zelfde Timor veroverde volkereu aldaar verkocht en een gedeelte er van te Batavia in het slavenkwartier geplaatst?

Welke redenen bestonden er dat men in den dienst der Comp. zoo "varieeren" en dezelfde zaak dan dus en dan weêr zoo begrijpen wilde? Wat zouden de Timoreesche Koningen en Hoofdbondgenooten van zulke wispelturige handelwijze moeten denken? Zouden ze de Comp. wel ooit meer vertrouwen? Bestond er eenige hardheid in die behandeling en was het integendeel niet ten uiterste billijk dat de Comp. schadeloos werd gesteld voor de gemaakte oorlogskosten?

Was het onder Christen-Mogendheden niet alom in het gebruik de krijgsgevangenen tegen malkanderen uittewisselen en de overschietende van de eene of andere partij voor geld te rantsoeneeren?

Wie was er die ze tegen 60 Rijksdaalders van de Comp. "redimeeren" wilde? immers niemand!

V. R. aarzelde dan ook niet het gehouden gedrag van P. in dezen "ten uyttersten en bij reiteratie te justificeren" en alle gevangenen Landoneezen voor slaven te verklaren van de Comp.; doch daaronder niet te willen begrijpen de 300 , die zoo als bij resolutie van den 24. Sept. gezegd werd, "particulier te zijn "overgezonden" voor P. gereserveerd te laten, terwijl hij vermeende dat P. zich hierover diende te zuiveren.

Hij v. R. vermeende verder, dat de "overgave op discretie" voor een ieder die lit woord maar verstond, geen "speculatie" of twijfel meer overliet om de veroverde volkeren voor krijgsgevangenen of slaven te verklaren, en dat het pardon, op zulke voorwaarde verleend, niets anders in zich sloot dan alleen lijfsgenade.

Ook van Rheden verzocht, dat dit zijn advies in de notulen van de vergadering zou worden opgenomen.

De Buitengewoon Raad de Nijs conformeerde zich in allen deele met het advies door den Direct.-Gener. ingediend. 
De Buitengewoon Raad van Basel verklaarde terug te komen op zijn gegeven advies op den 25 September en 17 Nov. te voren, en alsnu zich te conformeeren met hetgeen de Heer van Rheden had geadviseerd, met de bijvoeging, dat hij vermeende, dat men P. ter zake van de door hem terneder gestelde impertinente expressiën bij zijne commissoriale papieren behoorde te veroordeelen in eene geldelijke boete van 1000 rijksdaalders ten behoeve van de armen.

De Buitengewoon Raad van Riemsdijk verzocht aanteteekenen, dat hij bleef persisteeren bij zijn gegeven advies op den 24 September, terwijl hij bovendien van gevoelen was:

10. Dat uit het $5 \mathrm{e}$ en $6 \mathrm{e}$ Artikel van het laatst gesloten contract te Timor alle de aanstostelijk en verregaande bewoordingen tegen de Portugeezen, Spanjaarden, Franschen en Engelschen (waardoor dat contract van geen nut was) moesten geroijeerd en de verantwoording daarvan voor P. worden gelaten, als daartoe van de H. R. geen "kwalificatie" te hebben gehad.

$2^{\circ}$. Dat de Tandoneezen op̣ vrije voeten moesten blijven om de redenen bij zijn vorig advies vermeld, en

3o. Dat P. over zijn oneerbiedig schrịven in zijn rapport, behoorde te worden veroordeeld in eene boete van 1000 zilveren ducatons ten behoeve van de armen der stad Batavia.

De Buitengewoon Raad de Klerk gaf in de vergadering over twee verschillende geschriften, het eene over het door P. verrichte in de Timoreesche commissie, het tweede over het contract door P. met de Vorsten van Timor gesloten.

Betrekkelijk het eerste gaf hij te kennen: dat hij op den 24 September bij provisie had geadviseerd, dat de door P. aan de H. R. opgezonden veroverde Landoneezen wel en terecht tot slaven waren gemaakt.

$\mathrm{Na}$ het lezen van het rapport en de daarbij behoorende bijlagen zou hij nu de eer hebben zich wat nader te verklaren over de "eigenlijke reden en motieven die hem_daartoe hadden "geleid," daar het - zonder nog van het recht des oorlogs te spreken - gegrond was op de aloude staatsbeginselen die de Comp. van haar begin af tot op heden om de Groote Oost, omtrent de veroverde rebellen altijd had staande gehouden.

Tot bevestiging daarvan vond de $\mathrm{Kl}$. zich verplicht verschillende gevallen van denzelfden aard aan te halen, eensdeels om 
de H. R. " een levendige schets te suppediteren van de funda"menteele" bewijzen, die hij vermeend dat voor zijn advies zouden pleiten; ten tweede ook een idée te geven van de gevolgen die uit het bij meerderheid van stemmen genomen besluit zouden kunnen voortvloeien.

Hij begon met de verovering van Banda in 1621 door Coen, toen deze ruim 800 Bandaneezen, die zich op discretie hadden overgegeven naar Batavia had gezonden ter beschikking van de H. R. "die uyt een bijzonder medelijden en politique insigten "dito veroverde een plaats aanwezen om hun bestaan naast an"dere vrije volkeren te soeken." Dan nauwlijks had dit plaats gevonden of zij sloten zich aan in een verbond met den Koning van Cheribon om verraad tegen de Comp. te plegen; toen werden deze "Christen-haters niet alleen in de ketting ge"klonken, maar het ministerium van Banda gelast, al dat "verradelijk gebroedsel op te vatten en na herwaarts te trans"porteren, om naast humne landslieden te worden getrac"teert." 1 Bij die van het jaar 1683 zou de H. R. kunnen ontwaren, dat de "Dammenezen van de kwaad geïntentioneerde "negorijen, om de wille van de extirpatie, op een gelijke wijze "ten getale van 134, zijn voor slaaf verkogt."

Zoo was ook de Commissaris Speelman bij het vredestractaat met de Vorsten van Celebes "sonder de minste afwijking blijven, "urgeren op 1000 Makassaren tot een gedeeltelijke vergoeding "van de oorlogskosten." Toch kon dit geenszins in vergelijking worden gebracht met het gehouden gedrag van den Javaschen Veldoverste Couper, daar deze ua den vermaarden slag bij den berg Cacapan tegen den rebellerenden Pangeran Troeno Djojo 4000 veroverde Madureezen tot slaven had verklaard.

De H. R. zou deze gebeurtenissen nu wel onder de gevallen van den ouden tijd kunnen rangschikken, maar had de Admiraal en Veldoverste Smout met de veroverde volkeren voor de stad Goa wel anders gehandeld, en had men in de jongste expeditie te Boeton niet op een gelijke wijze geregeerd?

Was de H. R. daarenboven ter bekoming van eene behoorlijke en rechtmatige satisfactie niet blijven staan op het voldoen van 1000 slaven, ter vergoeding van het nadeel door dien Koning zoo lichtvaardig aan de Comp. toegebracht. Hadden de Hoofdbondgenooten van Timor niet eene "reeks van diergelijke exem-

1 Vide Haar Edelens missive van den jare 1622.

Downloaded from Brill.com๑4/26/2023 09:36: ๑8AM 
"pelen soo in de dagen van ouds als bij onse tijden aan Uw "HoogEd. uitgelevert" vooral ten tijde van het Opperhoofd van den Burg, en waren die veroverde volkeren niet daar tot slaaf verkocht of hier te Batavia in het slavenkwartier geplaatst? Had de H. R. in de besoigne van 1755 over Timor niet besloten die van Tamahale, Adanare en Trong, over humne hardnekkigheid tegen de Comp. en ongeoorloofde correspondentie met de Makassaren, mede eens te kastijden, opdat ze daardoor cens zouden gevoelen de smartelijke gevolgen van humne onbezonnen en trouwelooze bedrijven?

Hadden die van Tando in datzelfde jaar de Hoofd-Bondgenoten niet geforceerd tot het op de been brengen van een leger van $1200 \mathrm{man}$, en had niet het Opperhoofd Beijnon na zooveel beweging daarvan gemaakt te hebben, zich tevreden gehouden met eenen Balier, die men voorgaf den toemmaligen oproermaker te wezen, en werd die algemeene rustverstoorder niet voor 50 jaren naar de Kaap verbamnen? Hadden diezelfde Tandoneezen niet even na de verzending van dien banneling nieuwe onlusten gesmeed?

In zoo verre, dat P. bij zijne komst aldaar onmiddellijk gehouden was geweest een onderzoek in te stellen naar de verregaande verwijderingen tusschen den Regent Geolima c. s. ter eene en den Prins Regent, den Tommongon Nay Laffa en den broeder van den Prins ter andere zijde, om door zijne tusschenkomst zoo het mogelijk was die oorlogzuchtige bedrijven tot eene bekwame schikking te brengen. Dit had P. "onder obser"vantie van de applicabelste maatregelen die een vigilaut en "voorsigtig minister in sulke accidenteele omstandigheden " volgens het hegrip van de Kl. ook betracht. Want hij had alvorens zich "wijsselijk geinformeert" naar den wezenlijken en eigelijken aard en oorsprong der geschillen, in hoeverre die "hart"nekkige gedoentens zich hadden geëxtendeert" en door wat middelen en wegen zij naar de wetten en gewoonten van het land konden bijgelegd of gestraft dienden te worden. Men ontwaarde dit uit ziju rapport; daarin stond zeer duidelijk opgeteekend: dat de Tommongon Nay Laffa benevens zijne aanhangers bij voortduring de wapenen hadden opgevat, omdat ze humnen wettigen Regent niet hadden en dat de zoon van den overleden Koning meerderjarig was. Dat de regerende Regent Geolima, wel verre van de regeering aan zijn pupil te wilien afstaan, die trachtte te usurperen " en op zijn eigen zoon Dale te laten 
overgaan." Volgens humne verklaring was die zoon een kwaadaardig sujet en over den Regent hadden ze zich ook te beklagen.

Het onderzoek in deze door P. had hem overtuigd, dat al hetgeen ze hadden aangevoerd met de zuivere waarheid overeenkwam, zonder daarvan echter iets aan de klagende partij te laten blijken en wel om de volgende redenen:

1. omdat Geolima de Regent was die door de H. R. was geapprobeerd, zeker door misleiding of op eene verkeerde voordracht van het Opperhoofd of der Rottineesche Regenten;

2. omdat de Prins nog wat te jong scheen;

3. om den Tommongon Nay Lafla niet te stijven in zijn oproerige voornemens;

4. omdat het niet was geoorloofd zijn recht door oproer te verkrijgen en

5. omdat de "Comp. NB. den arbitrairen rechter en de cidador" der verschillen onder deze volkeren was en moest blijven.

$\mathrm{Nu}$ P. den oorsprong der voortdurende opstanden ontdekt had, vervoegde hij zich "om niet van den weg der "voorrigtigheid af te wijken " ten overvloede aan den Landraad, ten einde te veruemen met welk oog "dese troubelen aldaar werden beschouwd." Deze verklaarde zich ten voordeele van den Regent, onder betuiging dat de Tommongons "schelmen " waren die tot voorbeeld van anderen dienden te worden gestraft. Ze bleven persisteeren bij hunne vorige " doleantiën" zonder meer. "Hoe seer ook den Commissaris van 't contrarie was versekert" stelde hij hun, om de vijf opgegeven redenen, en om 's Comps. respect met relatie tot den door den H. R. geapprobeerden Regent staande te houden, niet in het ongelijk, maar vroeg hen "welke voldoening in deze begeerden."

"Die doen 't er op aankwam maar eenelijk versogt, dat den "Commissaris, na sonder veel van den text aftewijken, als nu "geliefden te doen, dat 't Opperhoofd bij de eerste opsending van "Nay Laffa had behoren ter executie te stellen" te weten: dat de Tommongons naar Batavia mochten worden opgezonden. Al het onderzoek was voorafgegaan voor dat $P$. het arrest van de Tommongons had gelast, echter onder verzekering aan den Prins pupil, dat hij hem niet alleen onder bescherming van de Comp. nam, maar ook een voldoende satisfactie zou bezorgen, onder voorwaarde dat hij voortaan de partij der Tommongons zou verlaten. De $\mathrm{Kl}$, noemde dit " een edelmoedige promesse ten 
"faveure van dien Prins" waarvan P. zich zekerlijk niets anders kon beloven dan een spoedig herstel der rust.

"Want - vervolgt hij — wat sterveling, hoe penetrant van " oordeel en ervaren in Staatszaken kon hier voorzien, dat de "Prins pupil na soo een genereuse belofte, sig zoude tragten "te begeven bij een onder de wapenen staande hoop rebellen "; echter had men dit zien gebeuren, en de zaken van achteren beschouwd kon men mogelijk de vraag stellen, waarom P. deu Prins niet mede had gearresteerd, want dau had hij geen gelegenheid gehad om de gevangenneming $\operatorname{van}_{k}$ de Tommongons te Coepan, op het eiland Rotti "alomme te divulgeren" en dan had ook mogelijk de laatste opstand geen plaats gehad.

De Kl. wilde dit wel toestemmen, "mits dat den gantschen "aanhang van den wettigen Prins in sijn persoon hadde geresi"deert en den Commissaris van zijn edelmoedige behandeling sig "iets dergelijks had kunnen verbeelden." Maar daar het een "talent boven 't menschelijke was" alle dingen te voorzien, moest den allerschrandersten zich dergelijke gevallen getroosten en "wenden na de verdere regelen van Staat."

Doch - zegt hij — gesteld dat P. dien jongeling, tegen wien niets ten laste was ingebracht of den Regent Geolima in plaats vau de Tommongous eens in verzekerde bewaring had genomen, zou men dan niet op beter gronden de vraag kunuen doen: Hoe die gevangenneming door de gezamenlijke Koningen en Hoofd-Bondgenooten zou zijn opgenomen? Vooral de Regenten van de 13 Vlagvoerende negorijen, door wien de Tommongons reeds voor schelmen en deri door de H. R. geapprobeerden Regent voor wettig hadden verklaard " en of de Commissaris alsdan geen " erger lot van hevige troubelen en beroertens soude wesen te "beurt gevallen." Ja of het P. wel ooit mogelijk zou zijn geweest - die alles met de macht van de Bondgenooten moest verrigten - dien gevaarlijken oorlog te dempen? Wanneer de Kl. de adviezen van de Hoofd-Bondgenooten ten nadeele van de Tommongons en ten voordeele van den Regent ernstig overwoog, vermeende hij het tegendeel. In dat gevoelen werd hij versterkt wamneer hij in overweging nam de bereidwilligheid van de gezamenlijke Hoofd-Bondgenooten in het bijeenbrengen hunner troepeu om den Commissaris met een aanzienlijk leger tot demping van den opstand le ondersteunen. Waut nauwelijks verwittigd dat partijen weder humnen toevlucht tot de wapenen hadden genomen, zag men een voldoend leger oprukken, om onder het 
bevel van den Onderkoopman Ringholın, deze bị voortduring hardnekkig blijvende rebellen ten eenenmale te "raseeren;" ja zelfs de aanhangers van den Regent mede tot krijgsgevangen te maken en het district onder de welgezinde Regenten te verdeelen, tot een algemeen voorbeeld "voor die muitzieke natie." Die orders had de Commissaris "als een liefhebber " letterlijk uitgevoerd, in zooverre dat de hardnekkigen "na een hevig " gevecht genoodzaakt waren geworden humne eerste post te ver"laten en na de Onverwinlijke Klip te wijken, waar ze door " de troepen geblokkeerd werden, hetzij dan om hen uit te hon" geren of door feweld tot de overgaaf te dwingen. "Toen de belegerden dit bemerkten, zonden zij eenige gedeputeerden aan P. met verzoek om pardon, voorgevende dat zij den oorlog niet tegen de Comp., maar den " usurpateur" voerden, die als een tiran over hen regeerde; daarbij was hij niet Comps. gezind en die meermalen aan den Tommongon Nay I taffia een gouden keten had aangeboden, indien hij wilde toestemmen on de Portugeezen in te roepen. P. daarentegen verklaarde hun dat zij uithoofde van humne verregaande ongehoorzaamheid en "tu"multueuse bedrijven, prive authoritate" tegen den inhoud van het aloude en jongst gesloten contract, wel en te recht den dood hadden verdiend; doch dat hij, "de liefde voor de wraak "verkiezende, hun wel pardon wilde verleenen, mits dat de belegerden ipso facto de wapenen nederlegd en zich gezamelijk aan hem op discretie overgaven. 'Ze werden hiervan, door een briefje aan de belegerden, door Ringholm met de gezanten medegezonden, verwittigd, waarop ze aanstonds de witte vlag uitstaken en zich overgaven. Doch tegen de gedane belofte kwamen ze die niet na - waarin zij te kort kwamen vermeld de $\mathrm{kl}$. niet - zoodat ze onze troepen "al vrij wat spuls" zouden hebben gemaakt, zoo Ringholm niet verdacht was geweest ziju macht bijeen te houden en " de gantsche rebellige hoop te doen " omcingelen, waardoor hij eerst regt meester wierd en in staat "geraakte hun na de ordre op te senden." Te Timor aangekomen werden ze na aftrek van een derde - voigens de belofte aan de Bondgenooten gedaan - op de aanwezige schepen en vaartuigen gebracht. T'oen dit zijn beslag had gekregen, werd Ringholm nader gelast den Regent c. s. "maar mede naar T'imor te disponeren " en de overige Landoneezen als gevangenen op te zenden, omdat P. bereids maar al te wel onderricht was van Cieolima's gevaarlijk gedrag. 
Zonder zich daarover te bedenken of dit langer uit te stellen verzekerde P. zich van "dezen trouweloozen en Portugeesch "gezinden " Regent en zijne aanhangers, door hen in arrest op het Kasteel te zetten, ofschoon hij betwijfelde "of deese so " onvermijdelijke manier van procederen Uw Hoog Edelen niet "wat al te hart soude voorkomen"; maar het Staatsbelang en de noodzakelijkheid bracht dit mede, omdat, welke partij hij ook had gekozen om te herstellen, het toch even als in vroegere dagen " maar nieuwe oproeren soude hebben uytgeleverd."

Bij resolutie van den 23 Augustus 1756 zou het de vergadering blijken, dat $\mathrm{P}$. in de opzending der veroverde Landoneezen almede niet lichtvaardig had gehandeld, maar integendeel reeds te voren opgemerkt: dat die volkeren nu voor de tweede maal het gansche land door hummen opstand hadden verontrust; dat zij weerbarstige en muitzieke knapen waren, en daartoe kans ziende gaandeweg nieuwe onlusten veroorzaken tot ruine van land en volkeren, om zoo het mogelijk ware de welgezinde Regenten almede te disponeeren tot onderwerping aan de Portugeezen, zooals dit reeds meermalen door die volkeren was beproefd, inzonderheid "door den trouwloozen Geolima en zijn adherenten". De noodzakelijkheid vereischte, dat aan die booswichten, die zoo kort na de onderteekening het zoo heilig bezworen contract hadden geschonden, werd ten uitvoer gelegd het 10 de artikel van dat contract " dicteerende, dat aan de eerste " transgresseurs een eclatant paraat en gevoelig exempel zal " worden gestatueert, tot maintien van dies teneur en subsistentie " van de verbondenen, hun luijster en authoriteyt en afschrik " van alle anderen." Die volkeren zouden bij de terugzending - om de verwoesting van hun land - onmogelijk kumnen bestaan en nog veel minder op Timor, zoo om dezelfde reden, als om de bekende "tirannique behandelingen der vijf Koningen aan overwonnenen " zooals meermalen was geschied.

Alle die "deliberatiën en meditatiën " waren voorafgegaan vóor dat de hooge Landraad met $P$. als president het besluit had genomen tot de "finale opsending deser veroverde volkeren." Daar dit was geschied tot behoud van 's Comp. respect, zoo diende de H. R. "so eclatant niet te ageeren tegen het " gedrag van humnen Commissaris", daar hij genoegzaam alles had gedaan met rijp overleg en doorslaande bereidwilligheid van de Hoofd-Bondgenooten, die in dat gewest den Hoogen Landraad uitmaakten even op de kust van Celebes, en waarin 
het Oppernoofd van de eerste oprichting af aan, als de Comp. vertegenwoordigende, de Voorzitter was.

De H. R. had immers een nooit betwist recht om over 7aken van Staat en Oorlog, en voor zooveel "donatie" betrof, over leven en dood. Dit werd nog bevestigd door een op denzelfden dag genomen besluit, tot het herstel van de negorij Lando uit de omzwervende vluchtelingen, en het aanstellen van den wettigen Prins, aan wien door de Hoofdbondgenoten de zoon van den gearresteerden Tommongon Nay Lafla tot Rijksbestierder was toegevoegd, met restitutie van 300 gevangenen, waardoor die oorlog tot een gewenscht einde scheen gebracht te wezen.

Zou nu de H. R. "dat kostbare politique gebouw, door ons "hoogloffelijke predecesseurs met soveei sorg als wijsheyd opge"rigt, en waarop de gantsche eendragt van 't magtige Celebes "en alle dese eylants volkeren schijnt te rusten en 's Comp. "finale magt uyt bestaat, zo eensklaps den bodem inslaan of "enerveren van sijnen gewonen loop? Wat heeft de Maatschappij "Hoog Edele Heeren daarvan te wagten als een chaos van "broulleriën en continueele oorlogslast, mitsgaders еeu present "verlies van 80 à $f 100,000$, die voorwar in dese dagen so "gemakkelijk niet te bekomen zijn, ten minste niet diende ver"worpen, om 't ten dage der besoigne geadvanceerde en genoteerde "bij de daarvan geformeerde resolutie, behelsende circa een for"meele improbatie van de gantsche behandeling" en wel:

1. omdat P. bij instructie tot zoodanigen handel niet was bevoegd;

2. omdat hij de Tommongons zonder verder onderzoek had laten arresteeren, daar P. zelve betuigde dat hunne klachten in waarheid bestonden, en :

3. daardoor de gelegenheid gegeven tot het vluchten van den Prins;

4. maar "bovendien willens N. B. de grondslag had gelegt" tot den daaruit ontstanen opstand en eindelijk:

5. om het verleende Pardon vóor het laten waaien vau eeu witte vlag en het verbreken van zijn gegeven parool.

Konden die "vijfledige argumenten bij de H. R, ingang vinden of overeen gebracht worden met het gehouden gedrag van P., dan fiat. Hij de Kl. die gewoon was om bij alle gelegenheden zijne ge dachten naar ziju vermogen op te geven "concludeert, "ten faveure van deu Commissaris": dat hij in het algemeen en bijzonder tot het ten onderbrengen vau dien ${ }^{*}$ rebellerenden hoop alles 
gedaan en verricht had, wat voorzichtige Generaals, Kommandanten, Regenten van steden in Europa en de generale Opperhoofden van 's Comp. Gouveruementen en Kommandementen in deze gewesten enz. gemeenlijk in geval van opstanden gewoon waren te doen, op grond van het tot hiertoe stand gegrepen systema en de leer van de oude en hedendaagsche Doctoren. Want zeide niet de groote Cicero in zijn $10 \mathrm{en}$ en $16 \mathrm{en}$ brief: "denkt niet dat in schielijke en gevaarlijke gelegenheden 't advis "van den Raad en 't volk moet worden versogt"; volgt dien weg "die 't Interest van de republiek u aantoont, want soo "Brutus had gewagt na 't goedvinden van den Roomschen "Raad, was hij en gantsch! Galliën verloren."

De wet der verdediging wordt - volgens een vermaard rechtsgeleerde - niet voorgeschreven door de menschen, maar net alle menschen te gelijk geboren. Die wet "werd ons niet "verbeelt buyten ons" maar ze was in 't bimnenste van onze harten ingedrukt; wij hadden die eerder gekend als geiezen; eer begrepen als geleerd, en "bij ons zelven eerder gevonden "als van auderen ontfangen." Die beroemde schrijver toonde duidelijk aan, dat men gekwalificeert of niet, geweld met geweld mocht afkeeren.

$J_{a}$ zelfs scheen hij van alle verzuim vrij, die iets deed hetgeen de strenge wet der noodzakelijkheid medebracht, want de onvermijdelịke noodzakelijkheid makte nu en dan geoorlooofd, dat anders voigens de wet niet mocht wezen; "buyten dat een "minister, hoe onschuldig hij zich in sijne Commissie heeft "gecomporteert" in alle zaken die door de reden moest worden beslist, veeltijds "beknibbelingen subject" bleef; omdat men gewoonlijk zag, dat hetgeen bij Preter billijk, bij Paulus somtijds anders werd begrepen; inzonderheid in zaken die "twee"derhande bevattingen" hadden, en waarin men, tot eigen gerustheid, wel den voorrang aan "de eerlijkste presumtiën" mocht geveu, in overeenstemming met de les van den wijzen mentor aan Telemachus, want - zegt die geleerde schrijver — "daar "geen zekerheid te bekomen is, is het niet onredelijk de beste "waarschijulijkheid te volgen." Dit had meer of min ook betrekking op het $5^{\mathrm{e}}$ lid van de vroeger aangehaalde resolutie, of het verleende pardon door het laten waaien van de witte vlag, dewijl hierdoor gewoonlijk werd te kemnen gegeven om met den vijand te "aboucheren" hetzij over de overgave of "de "ingrediënten van de capitulatie" die de belegerden garne

4e Volgr. I. 
zouden willen bedingen of de belegeraars voorstellen. En het woord pardon, vergiffenis maar dewijl er het slotwoord op discretie achtervolgde, zoo kon men dezen oorlogsterm niet wel mogelijk scheiden van den algemeenen text, bij het rapport zeer duidelijk uitgedrukt, naınelijk: "Dat de Commissaris uyt een "bijsondere menschlievendheyd - want de dood waren zij volgens al de beschreven wetten schuldig -- "wel pardon aan de "rebelleerende wilde verleenen, mits dat sij sig ipso facto op "discretie aan hem overgaven - dat hoe men het ook nam, "toch niets meer zeggen kon als het behoud van hun leven."

Gaarne had de Kl. zịnn "schriftuurtje" hiermede willen sluiten, maar dewijl $P$. in de beschrijving van zijn rapport veele onbetamelijke, ja zelfs zeer aanstootelijke uitdrukkingen tot "laesie van de H. R. had ter neder" geflanst, - "die een "eigen lof en waanwijsheyd denoteren en die mogelijk haar "source hebben genomen uyt een al te groote verbeeldings"kragt", vermeende hij dat P. deswegens wel een "ernstige en "serieuse reproche" meriteerde, als hij aan de andere zijde, staande de vergadering, voor zijn getrouwe diensten in beide de Commissiën ${ }^{1}$ aan de Compe bewezen, diende te worden bedankt; vooral als hij zich als een man van eer zuiveren kou van den blaam, bij diezelfde resolutie hem ten laste gelegd, dat hij :3000 krijgsgevangen Landonezen aan zijne gemachtigden zou hebben overgemakt. Want wanneer dat zoo werd bevonden, was zijn gevoelen dat $\mathrm{P}$. "als 't caracter van $\mathrm{U}_{\mathrm{w}}$ "Hoog Edelens gevioleert hebbende, exemplaar moet worden "gestraft tot afschrik van alle trouwlooze, dan wel bij ouwaar"heid den eersten aangever van die verfoeijelijke faamroverij." Met het verzoek om het door hem genoteerde in de notulen der vergadering optenemen tot zijn decharge indertijd, eindigt hij. De volgende aanmerkingen in een afzonderlijk geschrift vervat, had de Kl. op het door P. gesloten contract te maken.

In Art. 4. stond: "alle drie maanden precies", dit zou om de "afgelegenheid van sommige Regenten kunnen worden veranderd in de woorden walle drie maanden of wel vroeger of later na "dat er zaken exteren van eenig belang, om ordinare modo door "den Landraad te worden afgedaan, met welkers decisie de ver"schil hebbende parthyen beloven sig volkomen te vreden te "sullen houden, op dat de goede harmonie herstelt en 't Rijk

1 Bandjermasin en Timor, 
"door 't corrumperen van 's Lands inzettingen en regten niet "verdeeld of met zijn totalen ondergang werde gedreigt."

Art. 5 laakte in zeer scherpe bewoordingen de tirannieke behandelingen dier Portugesen enz., waar men achter de woorden doen zien kon laten volgen:

"En ondervinden de ondragelijke vervolgingen der Portu"gezen en Toepassen, door 't onophoudelijk exerceren van aller"hande insolentiën, vexatiën, en concussiën, waardoor dese "eylands volkeren, niet alleen veele van hun vorigen staat en "luyster hebben verlooren, maar ook door die continueele woe"lingen sijn gebragt in de armoedigste omstandigheyt; inson"derheyt de Inwoonderen van de voor de Portugezen meest "blootleggende districten; tot welkers preventie de gəzament"lijke Koningen en Hoofd Bondgenoten, na goed overleg en "rijp beraad onder den anderen, op een solemneele wijse sijn "overeengekomen, de Nederlandsche Maatschappij sonder de "minste bedenking te erkemmen voor hun wettigen overigheyt. "Uyt dien hoofde als teflens belovende hoog gem. Compe als "hunnen magtigen Protector te sullen eeren, respecteeren en "gehoorsamen - met soo veel bereidwilligheyd als getrouwe "onderdanen gewoon sijn humnen wettigen Souverain te doen "en dat wel principaal in erkentenisse van de onwaardeerbare "goedheden bij soo veel gelegentheden van de Compe genoten: "de heerlijke voorregten, en preëminentiën, die de Compe in "alle redelijkheyd en billijkheyd aan sijne getrouwe vasallen "cedeert en de ontelbare andere motiven van een gelijken aard, "als maintinerende sonder ansien van persoon een yder bij "sijn aangeboren vrijheyd van Godsdienst, 's Lands wetten enz. "onder een continueele reflectie op de sijde der regtvaardigheyd "en als waaromme sij gesamentlijke Koningen en Bondgenooten "t welsijn hunner personen, landen en onderdanen ter harte "nemende, verklaren hoog gem. Nederl. Maatschappij houw en getrouw te sullen blijven. Met niemant van de Europese of "swarte natien hoedanig genaamt" (en zoo voorts).

Art. 6. Stond: "Als dan op een tirannique en onmensche"lijke wijze handelen", kon gevonden worden met de woorden: "als dan op een ondragelijke wijze handelen, de ge-ubjugeerde "van humne voorregten berooven, gelijk de meeste contractanten "van de Portugezen en Tocpassen al menigmaal was te beurt "gevallen, soo is "t" en zoo voorts.

Art. 11. Vond men: "de Roomae Papen "schijnt beter" door 
"list en bedriegerijen, onder den dekmantel van godsdienst en "beloften ter eene (en door onwederstaanbare gewelt aan de "andere zijde, sijn afgetrocken van humne soo heylig besworen "verbonden) en dus deerlijk vervallen onder de dwinglandye "van onsen algemeenen vijant, die Ao 1749 onder commando "van hun Gouverneur den Teniente-Generaal du Costa, onse "landen tragte te overrompelen en tot schande te vernielen met "een leger van 50,000 zielen, waardoor die Natie soowel humnen "wettigen Vorst deu Koning van Portuga!, om reden van de "daardoor geschonden vrede met H. H. Mogende Heeren Staten"Generaal, als bij onsen getrouwen weldoender de Nederlandsche "Maatschappij, sig heeft schuldig gemaakt aan landverraad, ge"quetste hoogheyd enz. Soo is 't" enz. tot "t woordje Bondgenooten, dat wel Vasallen diende te wesen.

Art. 18. Kon 't woordje "schandelijk" wel geexcuseerd worden.

Art. 20. Scheen de passage "van geen uytgesonderd" wat hard en al te veel beknibbelingen onderhevig; het was dus beter dat de kapitale artikelen van Negotie voor de Comp. werden benoemd.

Nadat al de adviezen gelezen en vervolgens de stemmen waren opgenomen, bleek het in de eerste plaats: dat de leden der Vergadering ten opzichte van het punt der bij resol. van den 24 September en 17 November van het vorige jaar voor vrije menschen verklaarde Landoneezen op de volgende wijze hadden gestemd :

De Gouverneur-Generaal, dat de Landoneezen moesten worden verklaard tot slaven.

De Directeur-Generaal voor vrije menschen.

Het lid van der Waayen, gedeeltelijk.

Id. van der Spar, slaaf.

Id. Hooreman, vrij.

Id. van den Velde, slaaf.

Id. Hohendorff, gedeeltelijk.

ld. van Rheden, slaaf.

Id. de Nijs, vrij.

Id. van Bazel, slaaf.

I1. van Riemsdijk, vrij.

1d. de Klerk, slaaf.

Zoodat de uitslag 6, 4, 2 was; de meerderheid hesliste der- 
halve dat de Tandoneezen voor slaven moesten gehouden worden, en als zoodanig en ten gevolge van dien voor 's Comp. rekening gehouden, dan wel in haar dienst mochten worden gebezigd. Alzoo werd besloten, met uitzondering evenwel van den Regent Geolima, met zijn huisgezin te zamen ruim dertig personen uitmakende, waarover en in het bijzonder over zijn zoon in de volgende Vergadering zou worden beschikt.

De zaak der Tandoneezen hierdoor nu "finaal" afgehandeld zijnde, ging de Vergadering over tot het colligeren der bedenkingen die ingebracht waren tegen den inhoud van het op den 9 Juni 1756 door den Commissaris P. gesloten contract met de Koningen, Regenten en verdere Rondgenoten te Timor.

Het bleek hicruit dat de Gouverneur-Generaal vermeende dat de anstnotelijke periode bij het je artikel door een bediende van de Secretarie behoorde te worden geroyeerd.

De Directeur-Generaal meende dat die periode stande de vergadering door P. in persoon moest worden doorgehaald en hij te dier zake bovendien excuus verzoeken.

Het lid van der Waayen adviseerde als de GouverneurGeneraal en om die periode bij de ratificatie te laten royeeren.

Van der Spar was mede van dat gevoelen.

Hooreman "sustineerde" dat de Fiscaal Zich daarover eerst behoorde te verklaren.

Daar het lid van den Velde niet ter vergadering tegenwoordig was, werd de le Secretaris Hasebroek naar hem afgevaardigd om zijn gevoelen hierover te vememen, en die terug zijnde ten antwoord bracht, dat v. d. V. zich met het contract vereenigde, mits dat het daarin te vinden buitensporige werd geroyeerd.

Het lid vmm Hohendorff zeide, dat de aanstootelijke passagiën door P. in persoon behoorden te worden doorgehaald.

Van Rheden evenals V. H. en bovendien moest de gewezen Commissaris excuus verzoeken.

De Nijs conformeerde zich met het gevoelen van den Directeur-Generaal. Van Bazel met dat van van Rheede, terwijl Van Riemsdijk meende dat de anstootelijke passagiën bij de ratificatic behoorden te worden geroyeerd.

De Klerk had zich hierover schriftelijk verklaard en was daarbij van gevoelen dat het aanstootelijke diende te worden geroyeerd.

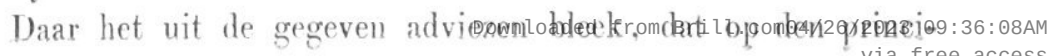


palen innond van het gemakte contract geen aanmerkingen waren gevallen, werd met algemeene stemmen besloten het te approbeeren en ratificeeren, zooals gedaan werd; doch tevens als een gevolg van de meerderheid der uitgebrachte stemmen, dat de aanstootelijke expressiën die in het 5 en 6 artikel voorkwamen, alvorens werden geroyeerd.

Een kleine discussie viel er nog voor op de vraag van don Secretaris Hasebroek, of het in de vergadering van dezen dag behandelde bij eene secreete dan wel gewone resolutie zou worden beschreven? bij meerderheid van stenmen ging men tot het laatste over, "ofschoon zijn Edelheid vermeende best te zijn, "dat sulx bij een secreete resolutie werd aangeteekend omdat "er passagiën bij voorkwamen die vereyschen gesecreteerd te "worden."

Den 1 April werden de beraadslagingen over de zaken van Timor in de vergadering hervat. Men besloot hierin, met "de "deliberatie en schikking over het presente Opperhoofd en ver"loste Sccunde", van welke men twijfelde of ze wel de vereischte talenten bezaten om op de door P. gelegde gronden voort te bouwen, te wachten tot het najaar, omdat de tijd om iets van belang ten uitvoer te leggen reeds te ver was verloopen, terwijl intusschen naar een bekwaam persoon kon worden omgezien.

Daar het van de uiterste noodzakelijkheid was dat aan cen speciaal persoon werd opgedragen het opzicht over de te ondernemen goudgraverij, zoowel daar waar de nieuwe post was aangelegd en waarvan de overgekomen monsters bevonden waren van ? caraat, als de goudrijke rivieren van Belo en elders warop men eenigen staat kon maken, vond men goed daartoe provisioneel te benoemen den Fiskaal aldaar Friesendorp, als de eenigste zijnde, van wien iets met vrucht te verwachten scheen.

Men nam echter in overweging dat, daar "de Timorezen door "een ongemeen superstitieusen geest gedreveu, niet te permoveren "zijn om de goudrivieren selfs van verre niet te naderen, sig "verbeeldende dat se dien ongeoorloofden stap met een onver"wijlden dood zouden moeten bekoopen, veelmin nog om ze te "bearbeiden", om bij aankomst der Balische slaven vaartuigen dat doorgaans gezonde en sterke menschen waren - een partij van 100 ì 200 daarvan voor de Comp. aan te koopen, en die zoodra mogelijk naar Timor te zenden om tot dat werk te 
worden gebrukt, en tevens te kumen strekken tot hume verdediging in geval van onverhoopte tegenkantingen en vijandelijkheden. Er moest echter gewaakt worden dat die slaven te voren niet in het ambachtskwartier werden gebracht om geen gevaar te loopen de beste slaven voor andere slechtere verwisseld te zien.

Het medegebrachte monster onbekende, doch zeer glinsterende erts, "waarin mogelijk iets zeldzaamst te vinden sij, als bij "smelting een soort van ongemeen hard metaal opleverende" zou men tot een proef naar het vaderland zenden en tegelijkertijd daarvan nog een partijtje van Timor ontbieden.

Ofschoon bij het onderzoek der van Timor ontvangen monsters indigo was gebleken dat daaronder er een was in 's Comp. tuin gekweekt, die van een zeer goede soort en met de eerste soort Jakatrasche overeenkwam - de Rottineesche was nog zoo zoo goed niet als de derde Jakatrasche - was het wel warschijnlijk dat die kultuur op Timor zou kunnen slagen, vond men goed om met de kultuur van de eerste soort nog een proef te nemen, maar de bedienden antebevelen "dat articul niet al "te sterk aantetasten, omdat het een zwaren lastpost is voor "onse Bondgenooten "

$\mathrm{Om}$ de Timoreezen op eene krachtdadige wijze en door een met hun belang overeenkomend middel antesporen zich met den uitersten ijver toe te leggen op het aanplanten van peper, bésloot men om in plaats van den bij contract bepaalden prijs van $4 \frac{1}{2}$ Rijksd. per picol, dat geen evenredige betaling werd geoordeeld, vooral omdat die kultuur nog in haar geboorte was en den Inlander daartoe moest worden aangemoedigd, hun 6 rijksd. toeteleggen voor den picol van 125 pond, dat was nog niet den hoogsten prijs dien de Comp. daarvoor betaalde; bij alle bekwame gelegenheden zou men tevens bakken met peperplanten derwaarts zenden.

Van de overgebrachte monsters lijwaten op Timor vervaardigd waren sommigen van een goede $k$ waliteit bevonden en met eenig avans te verkoopen; van die soorten die als de beste te boek stonden, zou men een corgie of twintig stukken tot een proef ontbieden, en de bedienden machtigen niet alleen zoo veel katoenen garens in te zamelen als hun mogelijk zou wezen omdat de ontvangen monsters van een zeer goede soort waren bevonden - maar bovendien aan de leveranciers dezelfde prijzen te betalen, als men op de hooofdplaats gewoon was, als: voor de eerste soort 45 , tweede 35 , derde 24 , vierde 18 rijksd., 
mits gesorteerd volgens de inonsters die men derwaarts zou zenden.

Dewijl bij het contract bedongen was, dat het $\mathrm{W}$ as voortaan de Comp. moest worden geleverd tegen 28 Rijksd. den picol van 125 pond en den picol sandelhout voor 3 Rijked., werd dit als zeer goede en voordeelige artikelen beschouwd en besloten daarvan zooveel als mogelijk was te laten komen, daar men vroeger aldaar voor het eerste artıkel 30 Rijksd. en voor het tweede insgelijks.merkelijk mecrder had moeten betalen.

Met het werken aan den koperberg te Ade zou men geen haast maken om niet te veel tegelijk onderhanden te nemen, te meer "om dat men hieromtrent wat temporiserende, inmiddels "door een nader onder\%oek van een bekwaam Opperhoofd, een "grondige kemnisse zal kumnen bekomen hoe het daarmede in der daad gelegen is."

Gesproken zijnde over de hooge noodzakelijkheid om het recht van eigendom op de Timoreesche eilanden voor de Comp. te conserveeren - die men met recht voor de sleutels der specerijgevende provinciën Amboina en Banda mocht beschouwen -- en dit op een onbetwistbare wijze te doen blijken, of het somtijds deze of geene Europeesche natie in den zin mocht komen zich daar te nestelen, onder voorwendsel "dat de Comp. daar nier "gepossideerd was", werd goedgevonden de bedienden aan te schrijven, om ten spoedigste op alle plaatsen daar de aankomst of postvatting van vreemden geoordeeld werd gemakkelijk te vallen, een tolk die schrijven kon te plaatsen, maar op zondanige eilanden waar dat niet uitvoerbaar was, merkpalen te stellen waarin 's Comp. wapen was uitgehouwen, en waarvan er reeds een partij in gereedheid waren gebracht om daarheen te worden gezonden; door deze matregelen verwachtte men dat alle nadeelige voornemens verijdeld zouden worden.

Maar daar P. het groote, zeer vruchtbare en volkrijke eiland Sumba (Soemba) beschrijvende, geen kleine zwarigheid opperde, dat het wel cens door deze of gene Mogendheid zou kunnen worden bezet, vond men goed ook daaromtrent de noodige voorzieningen te doen, en het Opperhoofd aan te schrijuen dat eiland nauwkeurig te laten onderzoeken, en de H. R. te berichten niet alleen wat er op dat eiland viel en welke producten het voortbracht, maar ook of het bezit daarvan voor de Comp. unttig werd geoordeeld.

Wat het voorstel betrof van $P$. om een gedeelte van het volk op dat eiland, die er naar zijn zeggen in menigte gevonden 
werden, vandaar te lichten ten einde daarmede de omstreken van Batavia te bevolken, kon men zich wel vercenigen, mits dat het met volkomen genoegen van die menschen geschiedde om naar Batavia te worden overgebracht, en dat daaromtrent geen geweld gepleegd noch dwang werd gebruikt.

Daar P. in zijn rapport zeer had aangedrongen om als tegengeschenken den Koningen en Regenten, snaphanen, kruid en lood aan te bieden, waardoor eensdeels zeer veel genoegen mede zou worden gegeven en ten tweede het veel voordeeliger voor de Compe was dan andere contrageschenken, besloot men daaraan gevolg te geven. Het kwam de II. R. des te noodzakelijker voor, omdat ze volgens het contract onder de wapenen moetende komen, daarvan wel voorzien dienden te wezen. Hoewel bij aanschrịiving van de Vergadering van $17 \mathrm{n}$ vall $29 \quad$ u ug. 1727 en 29 Sept. 1752 verboden was, om geweer, kruid moch lood an Inlanders te verkoopen of te schenken, achite men dit echter niet van toepassing op de Bondgenooten van de Compe te rijn, of schoon men tevens besloot daaromtrent met een spaarzame hand te werk te gaan.

$\mathrm{Nu}$ lag aan de heurt te hespreken de plaats waar en de wịze hoe de bij de vorige vergadering tot slaven verklaarde Landoneezen behoorden te worden verkocht. In de eerste plaats kwam men overeen honderd stuks van de beste uit de geheele partij voor de Compe te laten nitzocken om op Onrust dienst te doen, daar de zirken onder 's Comp: werkvolk thans groot was en noodzakelijk diende te worden aangevuld.

In de fweede plaats zou men de overige slaven door de vendumesters laten verkoopen in den tuin van den Gecommitteerde tot en over de zaken van den Inlander, die daartoe geschikt werd seoordeeld. Tevens vond men goed de familiën of huishoudingen, in 7.00 verre dit gevoegelịk kon geschieden, bij malkanderen in een koop op te veilen, onder uitdrukkelijke voorwaarde dat het alleen aan Christenen geoorloofd zou wezen, de slaven die Christenen waren te mijnen, terwijl de verderen door een ieder zou mogen worden gekocht.

De verkoop zou plaats hebben ten overstaan van twee gecommitterden uit het Collegic van Schepenen, ten einde aan hen zou kunnen worden vertoond en opgegeven de transporten en bewijzen van eigendon op de van Timor overgekomen slaven, om in gevolge van die bescheiden aan de koopers te worden afgegeven. 
Ten aanzien van den gewezen Rottineeschen Regent Geolima en zijn zoon, waarvan de eerstgenoemde volgens $P$. een voornaain "autheur" zou geweest zijn van de onlusten op dat eiland, en zich bovendien aan vele wanbedrijven had schuldig gemakt, nam men het besluit, hem met zijn huisgezin, uit ruim dertig personen bestaande, als staatsgevangene te Batavia aan te houden, en hun vanwege de Compe dagelijks twee gantangs 1 rijst te verstrekken en hun voor het verder benoodigde zelven te laten zorgen, waartoe men hun een stuk land in de Bovenlanden zou geven.

Maar wat zijn zoon Sibilla aanging, die blijken had gegeven van "een assurranten knaap te wezen" en om die reden voor een te gevaarlijk sujet moest worden aangezien om op Batavia te blijven, werd goedgevonden hem voor zijn leven naar Ceilon te verbannen.

Een der beide Tommongons was op de reis van Timor naar Batavia op het schip Osdorp overleden; de tweede, die uit hoofde van eene gevaarlijke ziekte was achtergebleven, en "mede een der capitaalste roervinken op Rotty was geweest." zou kumnen hersteld zijn, en datar hij met geen gerustheid aldaar kon verblijven, te meer dewiji het de Rijksvergadering was geweest die voorgesteld had hem naar Batavia op te zenden, werd het noodig geoordeeld de beuienden aan te schrijven, om, zoo hij mocht hersteld wezen, hem op te zenden.

De op de Landoneezen veroverde wapenen, die te Timor op $f 2607-12$ werden geschat, zou men op die plaats voor het geldende in het publick verkoopen en het meerder of minder rendement bij de boeken aldaar laten in- of afschrijven.

Bij het achtste artikel van het laatst gesloten contract was hepaald bedongen, dat de Timoreesche Kouingen en verdere Regenten eene aanzienlijke macht op de been moesten houden, om steeds gereed te wezen alle vijandelijkheden van een uitheemschen vijand te kumnen wederstaan; werd dit artikel letterlijk nagekomen, dan zou dit voor de Bondgenooten tot een zwaren last strekken. De vergadering was van oordeel en vond derhalve goed om het Opperhoofd aan te schrijven "ten reguarde "van dit onderwerp soo veel discretie te gebruyken als de "omstandigheden van tijden en záken sullen toelaten; mits"gaders de Bondgenooten niet te presseeren tot de precise

1 Een gantang $=13 \frac{1}{8}$ Amst, pond. 
"naarkoming hunner verbindtenis in desen, dan bij noodzake"lijkheid."

Op de bedenking door wat middel men een zekeren hoek lands, in het Oostelijkste gedeelte van het Eiland Ende gelegen, Larentoeka genaamd, aan Solor zou kumnen hechten, en daardoor tot "een Compe conquest maken", daar die plaats door P. voor zeer gevaarlijk werd te boek gesteld, zoo het de Franschen eens mocht in den zin komen zich daar te vestigen, bijaldien ze in hun oogmerk op Timor of een der omliggende eilanden niet mochten slagen, - werd na deliberatie besloten om de bedienden te Timor aanteschrijven, om bij de eerste bekwame gelegenheid op het nabij gelegen Solor "een wakker "posthouder te doen verblijf houden" - daar Larentoeka zon men zeide in het bezit was "van zeker swarte Portugeese Dona" en hem te overreden van geen middel onbeproefd te $\bullet$ laten "die een huwelijk tusichen hem en de voorsz. Dona soude "kunnen bevorderen", ten einde daardoor dat Land eerst aan Solor en vervolgens aan de Compe over te brengen, onder belofte aan dien man dat hij op de gunst van de H. R. staat kon maken, zoo hij zich in dit geval wel kwam te kwijten. Zoo het echter mocht gebeuren dat men daar "een officagieuser expedient" ter bereiking van dat doel wist uittedenken, zouden z.e dit bij humne brieven voordragen. Nog moesten ze trachten een middel uittedenken waardoor het kaneelbosch Rokko op Ende aan de Compe zou kumnen worden getrokken, tot welk einde "de bezitters gepersuadeert kunnen worden om in 't Bond"gevootschap te treden "onder voorbehoud van de order der H. R. dat aan hun buiten den kanceloogst een bestaan werd toegezegd.

Wat den "kregeligen Koning" van Koepang betrof, daar tegen zou men niets ondernemen zoo lang men het met hem cenigszins zou kunnen stellen, schoon het uit de nagelaten memorie door P. aan het Opperhoofd Beijnon genoegzaam bleek dat hij een zeer onhandelbaar en "dangereus subjeuct" was eu om die reden wel nauwkeurig diende te worden gadegeslagen. Mocht hij het echter al te grof maken en noch naar vermaningen noch naar dreigementen willen luisteren, dan werden de bedienden toegestaan "middelen van meerder klem in het "werk te stellen", dat wilde zeggen: "op te pakken en her"waarts op te senden ter nadere dispositie deser Regeering, "waar aan sig andere onbaudige en baldadige subecten alsdan "kunnen spiegelen," 
Op dezelfde wijze werden de bedienden gelast to handelen ten opzichte van den welbekenden Tommongon Tislolok, die hij diezelfde memorie werd beschreven te wezen "een snood en zeer gevaarlijk instrument."

Daar het uit de commissoriale papieren ten duidelijkste was gebleken, dat niet alleen de ongebondenheid der burgers en verde:e ingezetenen van Timor allen peil en maat te boven ging waarvan in de papieren van den burger David Schrijver een notabel staaltje werd gevonden, en welke "petulante knaap ter "zake van diverse wanbedrịven door den gewesen Commissaris "gecensureerd was" - mar dat zij bovendien door "konke"larijen en ongepermitteerde verkecringen met de Inlandsche "Regenten 't water aldaar zeer beroeren", achtte de H. R. dat het hoog tijd geworden was om die "breydelooze gemeente wat "te refreneren" en te noodzaken een redelijker gedrag te doen aannemen, en zon men de bedienden gelasten om zoodanige burgers die zich daaraan schuldig makten met de stukken ten hummen laste ter beschikking van de H R. op te zenden, doch dezulken, die zich wel en gelijk goede kolonisten gedroegen, niet alleen wei te behandelen, mar, indien het vereischt werd, ook te beschermen.

Wat "de negotie" aanging, besloot men goed te keuren de orders daaromtrent door P. gegeven en de bedienden te gelasten zich daaraan te gedragen en zonder afwijking optevolgen.

Bij het nalezen van het 24 artikel van het gesloten contract werd opgemerkt, dat de Regenten zich daarbij hadden verbonden, om gelijk als voorheen "alle zoogenaamde hofdiensten gratis aan "het Opperhoofd en verdere Comp. dienaren" te leveren, allerlei soorten van vee en andere levensmiddelen, houtwerken enz., zonder dat daaruit kon worden opgemant de hoeveelheid waaruit dit bestond; de H. R. achtte het noodig dat daarin een eenvoudige voet gevolgd werd "tot wering van excessiën of extorsiën" en ten dien einde de bedienden aanteschrijven om aan de H. R. bij de eerste gelegenheid te verstrekken, een lijst van al hetgeen door de Regenten om niet werd verstrekt of betaald moest worden. Mocht aldaar geen zoodanig reglement aanwerig zijn, zooals men wel verouderstelde, dan zouden ze een dergelijk reglement ontwerpen en ter goedkeuring aan de H. R. inzenden,

Door den Gouverneur-Generaal werd in omvraag gebracht, wat er zou dienen te worden beraamd ten aauzien van de door Downloaded from Brill.com๑4/26/2023 ๑9:36: ๑8AM 
P. op touw gezette negotiatie met den Gouvemeur van Lifllao tot het sluiten van een handelstractat. Na eenige overwegingen werd er besloten die zaak op haar beloop te laten, tot men de II. R. nader had geantwoord op hetgeen hem van 's Comp. wege was aangeboden; en dit te meer, doordien die zaak tot geen rijpheid kon worden gebracht omdat de Gouverneur alvorens dienaangaande nadere orders van den Vice-Roi van Goa moest afwachten.

Vervolgens kwam in behandeling wat men in het werk belioorde te stellen om de menigvuldige en gedurige kwellingen, tergingen en "manifeste" vijandelijkheden, die de zwarte Portugezen zoowel de Comp. als hare Bondgenooten andeden, en die van zoodanigen aard waren dat men ze zonder krenking van is Comp, authoriteit niet langer kon dulden, tegen te gaan. In de Memorie van P. werd dit uiteen gezet, doch de Gouvern.Gener. had te dier zake een opstel gereed gemaakt dat hij na lezing verzocht, in de notulen der vergadering op te nemen en van den volgenden inhoud was:

"Vermits de constitutie van zaken in deze tijden ten opzigte "vau Timor van gedaante schịnen veranderd en gevaarlijker "geworden te zijn, zoo diend men ook zulke vaste middelen " en maatregelen te nemen en in 't werk te stellen die alle "verre uitzigten van vreemde mogendheden, zoo voor tegen"woordig als voor die in 't toekomende zouden kunnen geb ren "worden, verijdelen en de sekerheid dezes gewigtigen oords ver"zekeren. Dier halven diend hier ten dezen opzigte ook prea"label geweten te worden, dat haar de Opperhoofden van Timor "en Solor in 't doen gelden van 's Comp. regt, eigendom en "pretensie op deze eilanden tegen de Portugezen of zoo 't "mogte gebeuren tegens nieuwe Competenten, door eene ver"ruiling niet meer moeten appuyeren op twijfelachtige regten. "Want alle donatiën, afstanden en renunciatiën die men van de "Koningen van Ternaten, ten faveure der E. Comp. vind, is "dat sij anno 1683 verklaart: dat Solor en die buurt al over "de 60 jaren aan d'E. Comp. wettig toequam en al haar regt "daarop aan haar afgestaan heeft; doch sulcx grijpt geen plaats "als na den oorlog met den Portugees; dus dient men nu "gansch andere wegen als men tot heden voor 't behoud dezer "landen ingeslagen heeft in te slaan, on ons dese landen te "verzekeren en den Portugees sonder de minste reeden tot een "vreedebreuk te geven, te dorn delogeren. Mijns bedunkens 
"meen ik niets zekerder en valabelder te zijn, als dat wij in "stede van ons op te houden met een reeks ongegronde be"wijsen, eenvoudig allegeeren dat ons ten tijde wij met de "Kroon Portugal in een openbaren oorlog waren, de Koningen "van alle dese Eylanden hebben ingeroepen en d'E. Comp. "versogt hun bescherm- en leenheer te willen sijn; gelijk sulx "sijn beslag heeft genomen met alle die Koningen, Princen en "Regenten, die tot heden in 's Comp. verbond continueren ; "schoon de Naymoutiers door opstoking der sogenaamde Por"tugeesen eenige deser Vasallen door geweld hebben weten van "hun verbond te detourneren, die egter heden weder dese "Naymoutiers hebben verlaten en in ons verbond getreden sijn; "behalven dat ons 't regt des oorlogs, waarin wij toen ter tijd "met Portugal gewikkeld waren, tot 't maken van conquesten "wettigden.

"Wat menigvuldige reden van klagen en van represaille te "nemen ons, dan de blanke dan de swarte Portugeesen onder "den naam van vrije volkeren sedert ons etablissement op die "eylanden successivelijk hebben gegeven, kan men, doordien alle "geschriften daarvan vol sijn, niet ignoreren; hebbende de Por"tugesen althoos en allesints de soo heilige tractaten van vrede "en bondgenootschap tusschen Sijn Allergetrouwste Majestijt "en H.H. Mog. de HH. Staten-Gener. op onwettige en frivole "pretexten gevioleerd; dan met "t arresteren van ouse vaartuygen "met volk en goederen, schoon die niet anders voeren, als "op plaatsen die ons en onse Bondgenooten en Vasallen toebe"hooren, en schoon ons volgens dat tractaat art. 7, $11 \mathrm{en}$ "12 geoorlooft is op alle Staten van S. M. handel te dryven. "Dan met het protegeren en ondersteunen onser onderdanen in "hunnen rebellie tegen hunnen wettigen Souverain d'E. Comp., "gelijk met die van Rotty, Timor en Solor met allerley ammu"nitie, kruyd en lood in den jare 1750 geschied is. En wanneer "ouse Opperhoofden haar daar over bij de Portugeesche Rege"ring beklaagde, durfden die nog wel de onbeschaamdheid "hebben frivolyk voor te wenden, dat dese eylanders wettige "onderdanen van den Koning van Portugal sijn "en dierhalve "verpligt was" hun NB. in dese rebellie te ondersteunen en "dese landen onder de gehoorzaamheid van S. M. te brengen; "schoon sij de minste schaduw van eygendom, regt of pretentie wniet konden aantoonen. En genomen sij eens konden bewijsen, "dat sij er voor de Hollanders op gevaren hadden, maakte dat Downloaded from Brill.com๑4/26/2023 ๑9:36: ๑8AM 
"nog geen regt van eigendom uyt; dat wij egter nooyt sullen "toestemmen, soo soude immers dat tot nadeel van haar lieden "de Portugesen selfs geallegeerd sijn. Want soo sij er op gevaren whebben is dat geschied voor den oorlog tusschen Portugal en "den Staat, in welken tijd wij dese eylanden hebben geconquesteerd en bijgevolg volgens de regten des oorlogs ons wettig "toekomen; ten ware sij die 't contrarie pretenderen kumnen "aantoonen, dat de Hollanders dese veroverde plaatsen, met't "maken van den vrede, weder aan Portugal hadden gecedeerd, "immers neen! Voorts met 't gevangen nemen en in de gevan"kenisse met allerlei soorten van tormenten te doen sterven nvan 's Comp. dienaren en onderdanen, die deze tormenten niet "als met de versaking van hnn gelove ten faveure der Room"schen konden ontgaan. Ja met het opstoken der Naymoetiers "om de Koningen van Belo, Ade, Manetoetoe en meer andere "Vasallen, van d'E. Comp. met geweld te dwingen hummen "wettigen souverain te verlaten en sig aan haar te onderwerpen, "sen eyndelijk met duysend insolentiën hier te lang om te ver. "halen, altoos onbeschaamdelijk en openbaar g'ageerd hebben. "Dog iets, dat niet alleen tot verwondering van de gansche "wereld maar van de minst geciviliseerde natiën moet strekken, "en dat S. M. van Portugal, volgens derselver equiteyt en "onbeproefde regtvaardigheyd, als sulke gruweldaad van hare "ministers ter ooren komt, zal doen straffen, is geweest, de "openbare aanhitsing en ondersteuning der Naymoetiers of soge"naamde swarte Portugesen, die in den jare 1750, door de "hulpe, den raad en de ondersteaning der Roomsche Priesters, "onder commando van den Teniente Generaal Gaspar du Costa, met "'s Konings van Portugals vlag, standart en baniere, bij haar el "Real genaaint, niet allen sooverre hebben durven emanciperen " om met 50,000 gewapende uyt die natie het grondgebied van " ons onderdanen en vasallen te veroveren; 't selve met moorden, " rooven, steelen en 't plegen van allerley gruwelijkheden door "te trekken, maar sonder de minste declaratie de stoutheyd " gehad haar tot op een $\frac{3}{4}$ uurs na, voor ons fort Coupang te "vertoonen, met die intentie 't selve te overrompelen, stormen" derhand in 't nemen en alles gevankelijk weg te voeren, hadde "de Goddelijke Voorzienigheyd, die altoos in sulke snoode onder" nemingen een mishagen heeft, daarin niet voorsien en onse " verweerende wapenen gesegend. Dir bewijst seker brief van "desen Teniente-General aan den Koning van Anarassie, die 
"sig bij hem gevoegd had, geschreven, en dic of vermits desen "Teniente-General in dese actie met meest de gansche magt op "'t slagveid bleef, bij hem gevonden is. Integendeel sal men " aan de kant der E. Comp. van haar Etablissement aldar, " alle mogelijke inschikkelijkineid, toegevendheid en bewesen " diensten in tijd des noods gewaar werden, dewelke die on" dankbare niet ais in hare turbuleuse desseynen hebben gestijfd " en gesterkt; nooyt begeerd hebbende op onze regtmatige klag"ten, protestatiën en vertoogen, hoe gefundeerd en overeen"komstig die ook met de allerheyligste tractaten en 't regt der " volkeren waren, eenige de minste satisfactie te geven, maar " integendeel ons arrogant daarop geantwoord en aile mogelijke " afbreuk en hinder in onse of onser onderdanen landen doende; " ageerende ieder Gouverneur van Liphao despoticq na sijn eygen "welbehagen met ons, onse vasallen en onderdanen; sig om 't " eloignement weynig of niet storende aan de ordomuntiën van " sijnen Souverain en nog minder on die van den Vice-Koning " van Goa. Interpreterende alles na humne caprice, quaad ge" moed of na den aard humner imhaligheyd; stoorende haar seer " weynig of sulx conform de tractaten en billijkheid was of " niet. Invoegen dat wamneer onse vasallen en onderdanen " allerley smaad, hoon, schande en schade wierd aangedaan en " toegebragt, en de zaak al te openbasar was, dan dat men die " kou ignoreren, dese Gouverneurs schielijk de schuld op de "Swarte Portugesen of Naymoetiers gooyden; en wanneer wij in de "tweede instantie satisfactie en voldoening over diergelijke ge"doentens eyschten, was altoos het antwoord deser Gouverneurs, " dat sij over deze Naymoetiers of Swarte Portugesen niets had" den te zeggen. Dat de Koning haar niet meer voor sijne onder"danen kende; dat sij afvalligen waren, levende sonder wet of " Koning onder een Hoofd, die sij Teniente-General inoemden, "haar hadden te samen gerot, en dat sij Gouverneurs selfs vau " dese Naymoetiers beoorloogd wierden. Gelijk dit onder anderen " het zeggen van den Gouverneur Corea was, in sijuen brief sub "data ....? geschreven, ter gelegenheid dit Opperhoofd en deu " Raad solemneelijk tegen de infractie der tractateu en selfs 't " aanhitsen der Swarte Portugesen, om een soo gruwelijk atten "taat, als dat van ons onverwagt met 50,000 man, met meening " ons fort te overrompelen en ons land te vermeesteren, gelijk "reeds hiervoren gesegt, te onderuemen, protesteerde en satis"factie eischte. Maar 't tegendeel is gebeurt, so dikwijls dat 
"Wamneee wij of onse vasallen slegts deze roovers en stroopers " verweerender wịze afkeerden en uyt onse limiten verdrijven, "dan weten de Gouverneurs en missionarissen niet hoe enorm, "hoe swart, hoe hoog, hoe lang, hoe breed sij dese misdaad "sullen uytmeten. Dan sijn 't geen roovers, stroopers, afvalligen "sonder Koning of wet levende, en aan niemand obediërende " volkeren, maar goede en getrouwe onderdanen van S. M. van "Portugal. Sict den brief door den Gouverneur van Liphao " onbeschaamdelijk, naar de nederlaag en "t verjagen der overige "nog ontkomen en aan ons ministerium op Coupang geschreven. "En dus hebben haar, volgens dier Gouverneurs zeggen, de Hol"landers en hare vasallen, omdat se hun fort niet hebben laten " attacqueren en niet goedwillig met vrouw en kinderen, have " en groed overgeven en alles gevankelijk weg laten voeren, maar "desen snooden hoop met de segepralende wapenen verjaagd, "schuldig gemakt aan een formeele vredebreuk met de croon "van Portugal; schoon de Gouverneur Corea, een jaar van te " voren, op de klagten van van den Burg over desen onverwagten "inval der Swarte Portugesen antwoordde, dat deze Naymoetiers "absoluut geweygerd hadden hem, in 't afraden van de executie " deses gevaarlijke proyects af te sien, te gehoorsamen; daarbij " voegende dat hij over dese voikeren, die over lange als vrije " waren aangemerkt en niet onder hem maar onder de Teniente"General, die sij selfs verkosen stonden, niets te gebieden had. "Ziet sijnen brief aan 't ministerium van Coupang in antwoord " onser doleantiën geschreven.

"Uyt alle dese dingen blijkt dan someklaar, dat 't de Por"tugeesche natie op Timor, door middel deser Naymoetiers of "Swarte Portugesen, die se, soo reeds gesegt, dau eens rebellen, " baldadige roovers, stroopers en volkeren die geen heer of wet "kemnen als die zij selfs na hun welbehagen kiesen, en dan " weer goede en getrcuwe onderdanen van S. M. van Portugal " noemen, nadat het met 't belang en intrest der Gouverneurs " overeenkomt om ons te chagrineren, nooyt aan een pretext "sal mankeeren, om ons onse vasallen en onderdanen, door " middel deser Naymoetiers, die sij naar hun welbehagen en " wanneer sij sulx voor haar intrest of haren bizarren aard te " voldoen, noodig oordeelen, tot het rooven en stelen zooals " heden en dagelijks nog geschied, aanzetten.

"En dierhalven, 't sij dat dese Gouverneurs in 't allegeren " van ' $t$ een of ander gelijk hebben, dat is: dat dese Naymoetiers te Volgr. 1 . 
" wesentlijk onderdanen van Portugal of dat sı̣ afvallige en " rebellen van die croon sijn of niet; dit is altoos zeker en met " deser Gouverneurs eygen handschriften te bewijsen, dat sij " niemand gehoorzamen en dikwijls de Portugesen gewapender" hand aanvallen. En genomen 't ware eens waar, dat den Koning " van Portugal dese trouweloose hoop voor S. M. wesentlijke " onderdanen aaumerkt, sijn wij dierhalven verpligt sulke gruwe" lijke attentaten (als hiervoren aangehaald is) en gedurige "strooperijen en moorderijen die tot heden haren voortgang " hebhen, te verdragen? Spreekt het dan niet van zelfs, dat "wanneer wij vrugteloos aan onse sijde alles hebben gedaan wat "goede en vroome Bondgenooten verpligt sijn te doen, wij ten " alleruytersten verpligt sijn om ons volgens de wet der natuur " der volkeren en die der represaille een weg tot satisfactie ter " vergoeding van schade en tot herstelling onser ruste te banen, "willen wij ons niet schuldig maken aau een onverant"woordelijke nalatigheyd van een pligt, die wij onse onder"danen onvermijdelijk verschuldigt sijn. Ik segge dan nog, dat " $\mathrm{ik}$ om die suffisante reden, en om eens van dese enormiteyten, " onverdragelijke vexatiën, concessiën en extensiën eeu eynde te " maken, en voor altoos voor te komen, zeen de minste zwarig"heyd maak om de Opperhoofden serieuselijk te recommanderen " cens deze quaestie, die hoe ongefundeert ze ook aan de "kant der Portugesen mag sijn, echter niet nalaat ons, onse " vasallen en onderdanen veel schade en ongerustheyd toe te "brengen, en soo veel onheylen veroorsaakt, ja dat meer "is, die d'E. Compe met 't verlies harer conquesten drijgt, "bij wege van represaille met 't ouderbrengen en veroveren "deser quaeddoenders te determineren; ow alsoo sonder quetsing "der heilige tractaten of eenige reden van misnoegen aan sijn "aldergetrouwste Majest. te geven, de rust op dese eylanden, "so voor ons, als de Portugeesche natiën selfs, die dese gevaar"iijke ruststoorders vijandelijk hebben durven attacqueren en $" n$ og dagelijks drijgen te suilen doen, te herstellen en altoos "te verzekeren.

"Het eerste dat in sulcken geval den onderuemer van dit "werk behoord te doen, is, dat hij op de frontieren van ons "gebied, bij de goudgevende rivier Teytallia cen veldschans noet "doen opwerpen, of die geen die gordomneert is te doen vol"tooijen en met een redelijk guamisoen beset houden. Dat in "dier voegen gedaan sijnde, moet hij op d'ordmaire tijd en 
"plaats den landraad doen convoqueren, en wanneer verscheyde. "Koningen onse vasallen, en insonderheyd die van Belo, Ade "en Manitoetoe of die in de nabijheyd deser Naymoetiers resi"deren, weder over gepleegd geweld, roof en doodslag klagtig "su'len vallen, en van d'E. Compe humen eenigen Leenheer "hulpe en adsistentie sullen versoeken en aanhouden, zal 't Op"perhoofd en den Rad haar ordomeren dese hume klagten en "versoeken naar gemoede en in waarheyd inscriptis optegeven, "en door alleu die beleedigt sijn, onderteykend, indienen. Bịj "dit schriftuur, dat, om alle suspitie voor te komen, alsmede "van de overige Koningen humne Bond- en eedgenooten, de "Koningen van Rotty, Savoe, Solor e: Sumba, welkers inte"rest door dat tractaat aan 't onse onafscheydelịk, sijnde een "gemeen interest moet uytmaken, in de Maleische taal moet "geschreven sijn, moet sorgvuldig en getrouwelijk alles werden "aangehaald hoe dikwerf sij door dese booswigten sijn aange"vallen, de wijse hoe, wat schade s! hebben geleden; en dat "sij ingevolge 't laatste met den Commissaris geslooten tractaat "van d'E. Compe hun Leenheer maintenue en een soodanige "adsistentie versoeken; waardoor sij niet alleen kunnen hopen "desen schadelijken hoop van humne grenspalen te sullen kumien "verjagen, maar ook daarenboven bij wege van represaille "wegens de geleden hoon, smaad, schande en schade, soo"danig beteugelen en haar magt besnoeyen, dat sij nooyt "meer in staat mogen geraken sulke gevaarlijke attentatiën op "'s Compe bezetting te ondernemen, nog hore dierbare rust "in 't possideren humner goederen meer te turberen. Deduce"rende en protesterende verder, dat sij met dat te doen gan"schelijk niet van meening of van sints ziju S. M. van Portugal "daardoor te beleedigen; sijnde behaiven de menigvuldige de"claratiën van de Gouverneurs die deze menschen voor soo "danig als boven verm. is, hebben gedeclareerd, al te wel van "sijne getrouwste Majest. aequiteyt g'informeerd en overtuygd, "dan dat sij haar souden kunnen imagineren dat S. M. desen toome"lozen hoop voor zijne onderdaneu soude willen aanmerken, in 't "uytroeyen van een soo schadelijk nest volk; van een volk dat "niemand obedieert, levende sonder wet of regel, als die hun 't "geweld en de sugt, om van 's anderen sweet en bloet te leven, "inboesemd en aanwist, en die een weglooper van d'E. Holland"sche Comp gelijk Anthonio D'(Ornay humen cersten Teniente"Generaal geweest is, tot een stichter humner schadehije republica 
"hebben, die gesticht is in cen tijd van vasten vrede mot "Portugal, en dus in al sijn bedrijvens en te onderbrengingen, "even onwettig, ja die daarenboven diverse reysen selfs tegen "S. M. onderdanen, gevaarlijke desseynen hebben ondernomen, "en gewapenderhand gesogt sig meester van Liphao en 't onder"hoorige te maken, ja dat meer is, die in 't optrekken tegen "de Hollanders publicq durfden seggen, en dat ook aan den "Koning van Amarassi, die toen met haar te samen spande, durfden "schrijven dat soo dra sij de Hollandsche cattenoogen hadden "vermeestert sij Liphao ook souden attacqueeren, voor een vrede"breuk of infractie in de tractaten zal willen aanmerken; protes"terende voor God en de gantsche wereld niets door 't nemen "vau dese represailles in 't oog te hebben als hun een behoor"lijke satisfactie en vergoeding wegens soo veel geleden smaat, "hoon en schade te besorgen, mitsgaders de rust en zekerheid " onser Staten te versekeren.

"Dit gedaan sijnde behoefd 't Opperhoofd niets anders te doen "als dit volgend manifest aan de Liphaosche Gouverneur af "te vaardigen. 1)

"Dit gedaan sijnde, moet men dese vasallen laten ageren en "de uytlandsche vorsten tot haar adsistentie over laten komen, "voegende men slechts soo men wil een paar honderd wel gedis"ciplineerde Baliërs onder goede officieren en eenige weynige "Europeesen daaarbij, fourniserende haar sooveel kruyd en lood "ais sij gevoegelijker wijze noodig hebben; doch niet veel te "gelijk. En om alle confusie, questie en desordres voor te "komen, zal ten hoogst noodzakelijk zijn dat er een goed regle"ment gemaakt worde volgens 't welke alle de Koningen haar "stiptelijk zullen moeten gedragen. Alleen den buyt, bestaande "in krijgsgevangenen of andersints sal, na 't eyndigen van den "veldtogt, verdeeld moeten worden onder haar naarmate van den maandeel dat ieder in den oorlog heeft gehad. Want 't soude "niet billijk zijn dat iemand die met 500 man ten oorlog is "getrokken soo veel genoot als die geen die met 5000 geageert "heeft; de verdeeling moet door 't Opperhoofd en den Raad "geschieden, na alvorens sooveel krijgsgevangenen van de hoop,

1 Volgt cene opgave van de menigvuldige grieven hierboven reeds aangehatal. 
"als er noodig zijn, om tegen $10 \mathrm{Rd}$. 't ps. gerekend, de oorlogs"kosten goed te maken. En die hunne krijgsgevaugenen sulleu "willen verkoopen, sullen suix aan niemand anders als aan de "Comp. mogeu doen en daarvoor genieten voor een kloeke jongen "of meyd $10 \mathrm{Rd}$.

"Dit alles met een goed succes in dier voege verrigt sijnde, "daar niet aan getwijfeld moet worden, kan men dese verrigtingen "Inet min of meer veranderingen tot een model voor 't veroveren "van Larentoecque gebruiken. Want NB. ook dit nest staat "onder den Teniente.Generaal, invoegen dat wanneer dit ten "ondergebragt is Larentoecque ook moet volgen; doch daartoe is "weynig magt noodig en men behoeft slegts onse Soloresen, die "ons ook daartoe inscriptis moeten versoeken, te adsisteren, en "vervolgens met een soodanigen magt, als men deukt na de "constitutie van zaken en tijden te behooren, in 't Belonees in"rukken; hare goud uitleverende rivieren nauwkeurig examineren "en den Inlander met zagdzimnigheyd tot 't opduyken van 't "goud sien te persunderen, tot wij alle dese rivieren kemnen, "en de wijse door dewelke sij dat goud opduyken aan onse "vreemden 't sij Baliërs of andere, $\operatorname{dog}$ vooral geen Bougi"nesen sullen geleerd hebben.

"Dese vreemde opduikers van 't goud moeten 't Belonese be"setten, en men moet onder haar de allernauwkeurigste en "strengste discipline onderhouden; ook dienen sij, om den diefstal "ten opzigte van 't goud, dat een zoo kleyne volume is en so "ligt geborgen kan worden, onder een wet te staan, die 't "stelen van 74 reaal aan goud met de galij straft en alle min"dere feytelijkheden pro rato een strenge straf onderworpen "zijn. Dog dese vreemden moeten voor al niet van Batavia, "maar van Baly of de plaatsen daar men die negotieerd daar "naar toegebragt werden, en wameer sij in de quade mousson "door 't opswellen der rivieren buyten staat sullen sijn 't goud "op te duyken, konnen sij als dan haa: besigen met peper, "indigo en andere producten te planten."

Nadat over dit onderwerp breedvoerig was beraadslaagd en gelet was op het gevoelen van den gewesen Commissaris in cas subject, werd gosdgevonden en verstaan "dat snoode gebroedsel "niet langer te menageren", mitsgaders de Timoreesche bedienden op 't nadrukkelijkste te gelasten, bij de eerste hostiliteit die de Zwarte Portugezen, ten opzichte der Compe of hare Bondgenooten weder mochten plegen, zonder dat van 's Compe wegen daartoe 
aanleiding was gegeven, als dan dadelijk tot het nemen van represaille over te gaan en hen ten dien einde met de wapenen der Compe en die der Bondgenooten aantevallen, "mitgaders "des mogelijk totaal te ruineren, sonder welke strenge mat"regelen men ginter nooyt in ruste zal kumnen leven."

Vervolgens werd besloten dat door P. op eene voldnende wijze zou worden aangetoond:

$1^{0}$. waar de 100 personen waren gebleven die bij het veroveren van het Rijkje van Anthony Roetoedoe gevangen waren genomen ;

20. waar te vinden waren de 1300 Rijksd. van den verkoop der tuin van het gewezen Opperhoofd van den Burg;

30. aantetoonen of het familiegoud, dat door van den Burg den Koning van Amacone zou zijn afgedwongen, benevens de som van 270 Rijksd. voor twaalf vaten buskruid, - welke beide posten aan de Compagnie nog niet waren verantwoord te Timor waren ingevorderd of wel nog te Batavia moest worden betaald;

$4^{0}$. het overleggen van een gespecificeerde rekening wegens zijne gemaakte onkosten in beide Commissien ${ }^{1}$, en waarvoor hij verzocht had te worden schadeloos gesteld;

50. dat door hem zou worden aangetoond waarin de door hem uitgegeven buitengewone geschenken of goederen hadden bestaan, waarvoor hij vergoeding had gevraagd.

$\mathrm{O}_{\mathrm{p}}$ het voorstel van den Gouvern.-Gener. gedaan werd als nu goedgevonden en verstaan "de wijdloopige besoigne over 't "zakelijke bij het voorsz. Commissoriaal Rapport beschreven "staande, hiermede te houden voor finaal afgedaan." Over de andere daarin gevonden punten betreffende deze en gene partikuliere zaken en die aangemerkt of gerekend konden worden ouder de zoodanige die door de vergadering werden gedesa"voueert, zou niet spetiaal worden gedisponeert", maar het een en ander worden begrepen onder degene "waarover (hij P. "ten regten bij het afloopen dezer zaken ernstig staat gere"procheert te worden."

Hiervan bleef uitgezonderd de door den Directeur-Gener. bij zijn schriftelijk advies gedane vraag nopens de 300 honderd Landonezen, die P. aan zijnen gemachtigden had overgezonden, waarover de dispositie bleef uitgesteld tot een volgende verga-

1 Timor en Bandjermasin. 
dering, omdat de Direct.-Gen. niet tegenwoordig was; alsmede datgene wat bij het Rapport ten laste van den Klein Winkelier Aitsma was gebracht. Nog werd door den Gouvern.-Gener. ter tafel gebracht een afschrift van het 5 en 6 artikel van het met de Koningen en Regenten van Timor gesloten contract, "waarbij "Sijn Edelheyd hadden doen sublineren al 't geen ingevolge het "geresolveerde op den 29 Maart te voren, soude dienen te "worden geroyeerd" $\mathrm{Na}$ genomen inzage van dat stuk, werd verstaan, om al hetgeen daarbij onderhaald was bij de originele contracten, zoomede bij de daarvan gemaakte authentieke afschriften in dier voegen te laten doorhalen dat het onleesbaar werd, en dit te laten verrichten door den Eersten gezworen klerk van de Algemeene Secretarie. Hiervan zou niet slechts bijzondere melding worden gemakt bij de te ontwerpen acte van ratificatie, maar tevens de bedienden te Timor te gelasten mede zoodanig te werk te gaan met de aldaar gevonden wordende contracten.

De heer Hooreman verzocht aanteekening te houden, dat hij bleef persisteren bij zijn schrifteligk advies gegeven ${ }^{1}$ op den 29 Maart, en den heer de Klerk 2 dat hij zich refereerde aan zijue schriftelijke aanmerkingen op het contract en almede op den genoemden datum in de notulen der vergadering opgenomen.

Bịj resolutie van den 5 April werden de door $P$. met de Koningen en Regenten van Timor op den 9 Juli van het vorige jaar gesloten contracten geapprobeerd.

In dezelfde vergadering kwam nu weder ter sprake de zaak betreffende de 300 slaven die door P. naar Batavia aan zijne gemachtigden zoulen gezonden wezen, en waarover de Directeur-Generaal in de vergadering van 24 September zijn advies schriftelijk had ingediend, en alsnu nog verklaarde, dat hị toen niet anders geweten had of die menschen waren volgens de toen loopende geruchten alle Landoneesche krijgsgevangenen. Na penige beraadslagingen werd er goedgevonden en verstaan, die Ziak daarbij te laten berusten, doch de Raden van den Velde, de $\mathrm{N}_{i j s}$ en de Klerk "persisteerden bij hunne "op den 29 Maart ingediend en bij de ten dien dage geriomene "resolutie ingeschreven advies. ${ }^{3 \prime}$

Betreffende de klachten van P. over den Klein Winkelier werd gelezen een verantwoording vau dien bediende, als bij-

1 Blz. 456.

2 Als voren blz. 461 .

3 Zie blz. 460 . 
lage gevoegd bij het advies door den Direct.-Gener.op 29 Maart ingeleverd, en waarover nog het een en ander door hen werd in het midden gebracht, waarop de vergadering besloot met de verantwoording genoegen te nemen "mitsgaders die zaak te "passeren."

In de vergadering van den 13 Mei werden door den Gouverneur-Generaal ter tafel gebracht twee stukken hem door P. geworden, inhoudende "de gerequireerde elucidatie en verantwoording" op de vijf punten hiervoren op blz. 490 genoemd, en wel op het $1^{0}$. punt: dat de houderd gevangenen bij het veroveren van het rijk van Anthony Roetoekoe naar's lands wijze en aloud gebruik en ook volgens art. 10 en 11 van het nieuwe contract, na aftrek van den tienden persoon voor de Comp. waren toegewezen aan zekere Don Bastiaan van Amanoebang, een Broeder en eerste Rijksbestierder des Konings van dien naam en die ook het Hoofd der Belonese krijgsexpeditie was geweest, en volgens het aangevoerde, verzocht had hem die tot eene belonning te willen schenken. Dit argument werd in opmerking genomen en na ecnige deliberatie goed gevonden en verstaan, zich ten opzichte van dat onderwerp te houden voor voldaan. Wat het 2 de punt aanbelangde, namelijk het geld, gekomen van den verkochten tuin van het gewezen opperhoofd van den Burg, daarvan werd bij het rapport en in de daartoe hetrekkelijke. papieren gevonden: dat het niet alleen had bedragen de somme van $1300 \mathrm{Rd}$.; maar bovendien de opbrengst van de verkochte meubelen en slaven tot de nalatenschap behoord hebbende, na aftrek van alle onkosten, had bedragen de som van Rd. 24l16-20, dus te zamen uitmakende Rd. 3716-20. Deze gelden waren te Timor verrekend geworden tegen de lasten van den boedel, bestaande in het door van den Burg afgedwongen familiegoud van den des tijds gedetineerden Keizer van Amacone, ter somme van 5000 Rd.: nog $270 \mathrm{Rd}$. wegens de door hem onverantwoord geblevene 12 vaatjes buskruid; zoomede $7000 \mathrm{Rd}$. voortspruitende uit de pretensiën der vịf Koningen, voor de door hen geleverde materialen tot het in orde breugen van "den meergewaagden en zeer geextendeerden thuyn" van het Opperhoofd.

Deze som van Rd. 12270, die nog eenigszins kon worden verineerderd door eenige uitstaande schulden, waarvan de inpalming aan den Fiskaal aldaar was opgedragen, moest het kantoor Timor betalen; was die niet toereikend, dan moest te Batavia het ontbrekende uit den boedel van hem gevonden worden. 
De Vergadering hield zich met deze inlichting op de tweede vraag voor voldaan, en al verder werd besloten dat onderwerp buiten beslissing te laten tot de Majoor Faber, die de wed. van van der Burg had getrouwd, zich zou hebben verantwoord ingevolge het besluit van de vergadering van den 19 April.

Over het derde punt werd goedgevonden genoegen te nemen in hetgeen daarover door P. werd aangevoerd, namelijk dat hij kort na zijne terugkomst niet alleen de van Bandjermasin medegebrachte geschenken, maar ook het goud van den Koning van Amacoue en Lislolok benevens eenige andere van Timor medegebrachte goederen, aan den eersten Koopman van het kasteel had overgegeven en waaronder ze alsnog herustende waren.

Op het 4 e punt werd door $\mathrm{P}$. een rekening overgelegd van de uitgegeven geschenken enz. in zijne beide commissien groot Rd. 11933-35. Nadat deze door de leden was nagerien, bracht de Gouverneur-Generaal in omvraag of men daarop eenige aanmerking had te maken, waarop de Directeur-Generaal "voor sijn advies verklaart en doet aanteekenen" dat hij vermeende het ruim genoeg genomen zou wezen, als men hem hiervoor tweederde of Rd. 7955-38 toetelde, daar hij van gedachten was dat 't niet genoeg was zulke gegrosseerde rekeningen aan te maken, "nog zonder qualificatie ongemeene spendatiën te doen."

De leden van der Waayen, van der Spar, Loten, Hoore man, van den Velden, van Rheden, van Basel, van Riemsdijk en de Klerk oordeelden dat men hem de geheele som zou restitueren, nadat door P. zou zijn overgelegd de kwitantiën ten bewijze dat die onkosten werkelijk door hem waren gedaan.

De heer de Nys voegde zijn stem bij die van den DirecteurGeneraal, de Gouverneur-Generaal bij die der overige leden. De meerderheid besliste voor de teruggave der geheele som onder overlegging der verlangde kwitantiën.

De beantwoording van het 5 punt door $\mathrm{P}$. betrof hoofdzakelijk de te Bandjermasin door hem gedane buitengewone geschenken en behoeft derhalve hier niet te worden opgenomen.

In de volgende vergadering, den $17 \mathrm{Mei}$, werd door P. voldaan aan het genomen besluit van den 13 te voren; de leden namen daarmede genoegen en hiermede eindigde de zooveel gerucht gemaakt hebbende Commissie van $P$. naar Timor.

Zooals men zal hebben bespeurd, kwam P. er nog al wel af; het blijkt dat hij, hoewel de Directeur-Generaal en enkele 


\section{4}

leden der H. R. tegen zich hebbende, de meerderheid de schaal ten zijnen voordeele deed overslaan, zoodat er noch van suspentie noch van het betalen eener boete meer sprake was, ja hij zelfs niet gedwongen werd met eigen handen te royeeren de verregaande insolente uitdrukkingen, door hem in het gesloten contract tegen eenige vreemde natiën gebezigd, en daarvoor vergiffenis te verzoeken. 